\title{
Gradnje i obnove Umjetničkog Mladen Perušic paviljona u Zagrebu
}

Mladen Perušić
mladen.perusic@zg.t-com.hr

Pregledni rad/Scientific review Primljen/Received: 31. 05. 2015.

UDK:

727.7.025.4(497.5 Zagreb)

DOI:

http://dx.doi.org/10.17018/portal.2015.13
SAŽETAK: Umjetnički paviljon sagrađen je u Zagrebu 1898. godine kao centralna građevina s kupolom i bočnim krilima, osvijetljena sa stropa, prema tadašnjim europskim arhitektonskim obrascima za takvu namjenu građevina. U stoljetnom nizu građevnih mijena Paviljon je djelomice izgubio prvotni izgled, najviše 1938. u radikalnoj purifikaciji pročelja. Građevno stanje početkom ovoga stoljeća bilo je loše pa su stručne službe Grada Zagreba pripremile i provele obnovu od 2007. do 2013. U članku se iznosi tijek građevne povijesti Umjetničkog paviljona, od projekata i gradnje za izložbu u Budimpešti, rekonstrukcije u Zagrebu, niza projekata i izvedbi sanacija, do recentne obnove, s obrazloženjem konzervatorskog pristupa i prikaza radova obnove kupole, krovova i pročelja.

KIJUČNE RIJEČI: Umjetnički paviljon u Zagrebu, gradnja, građevne mijene, recentna obnova
$\mathrm{U}$

mjetnički paviljon u Zagrebu poznat je po svojim karakteristikama sačuvane arhitekture slobodnostojećeg objekta na trgu Zelene potkove, a i bogato urešen interijer tijekom godina nije bio mijenjan jer je u neprekidnom kontinuitetu javne namjene izložbene djelatnosti. ${ }^{1}$ S obzirom na nedavno izvedene radove, ovim se tekstom žele prikazati povijesne faze Paviljona i njihova valorizacija koja je bila osnovom za predloženu prezentaciju. Donose se do sada nepoznati podaci i pojedinosti o arhitektonskoj analizi zgrade, izvedenoj geometriji i konstruktivnoj strukturi, na osnovi arhivskih, konzervatorskih i restauratorskih istraživanja i izvedenog stanja, prema kojima je realizirana koncepcija konzervacije i restauracije građevine.

\section{Paviljon za poviest i umjetnost na Milenijskoj izložbi u Budimpešti 1896. godine}

U povodu proslave tisućljeća od dolaska ugarskih plemena $u$ karpatsku dolinu, mađarska vlada pripremila je 1896 . veliku izložbu u Budimpešti. Vlada Trojedne Kraljevine s banom Khuenom Héderváryjem, državnopravno povezana s Kraljevinom Ugarskom u sklopu Austro-Ugarske Monarhije, uz protivljenje oporbe, ${ }^{2}$ sudjelovala je na izložbi sagradivši četiri paviljona (sl. 1). ${ }^{3}$ Pripremu izložbe vodio je vladin povjerenik, vrstan gospodarstvenik, pravnik, prijatelj umjetnika Ivo Mallin, koji je s Vlahom Bukovcem osmislio i proveo ideju o Paviljonu za povijest i umjetnost kao čeličnoj konstrukciji koja će se nakon izložbe premjestiti u Zagreb i biti jezgra Umjetničkoga paviljona. Zemaljski izložbeni odbor raspisao je javni natječaj za izradu projekata s rokom predaje radova do 10. travnja 1895. Odabran je rad mađarskih arhitekata Florisa Korba (1860. - 1930.) i Kálmána Giergla (1863. - 1954.), ${ }^{4}$ koji su primijenili uobičajenu shemu za izložbenu namjenu i projektirali središnju građevinu s kupolom i dvoranama u krilima. ${ }^{5}$ Sačuvani dio natječajne dokumentacije (tlocrt, presjek, nacrt glavnog pročelja i tlocrt željezne konstrukcije s presjecima), kao i dio projektne dokumentacije 


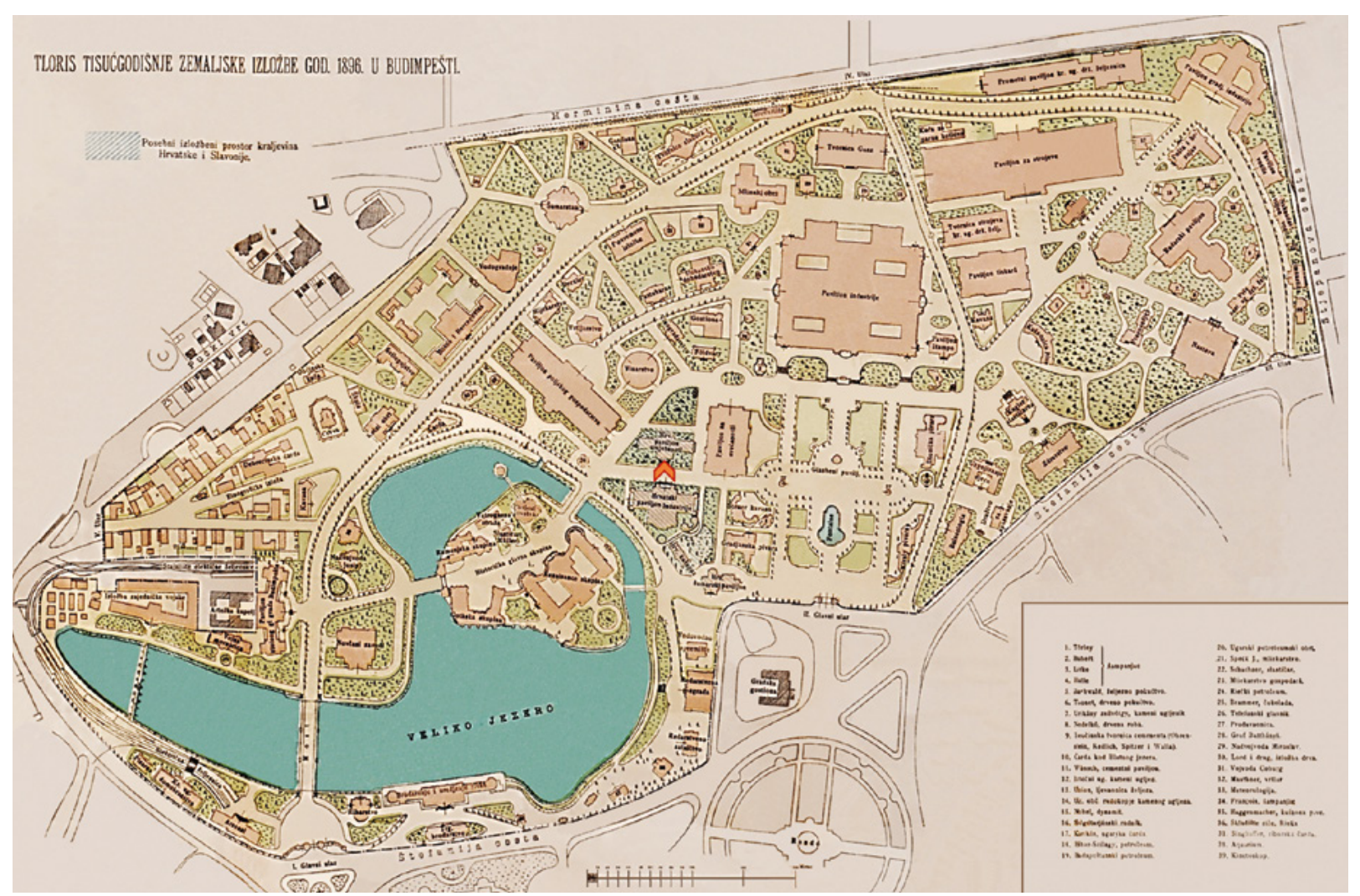

1. Tloris Tisućgodišnje zemaljske izložbe god. 1896. u Budimpešti (Kraljevine Hrvatska i Slavonija na Tisućgodišnjoj zemaljskoj izložbi Kraljevine Ugarske u Budimpešti 1896., 1896.)

Layout of the 1896 Millennial Exhibition in Budapest (Kraljevine Hrvatska i Slavonija na Tisućgodišnjoj zemaljskoj izložbi Kraljevine Ugarske u Budimpešti 1896, 1896)

(tlocrt) prema kojoj je paviljon sagrađen, vrlo su važni izvori informacija o prvotnim idejama, a onda i izvedbi. ${ }^{6}$ Omogućavaju i praćenje izmjena u izvedbenom projektu $u$ odnosu na ideje iznesene $u$ natječajnom radu.

U natječajnom tlocrtu paviljon je koncipiran kao složenija cjelina s više elemenata. Bočne izdužene dvorane na kraćim stranama rastvorene su s po tri otvora prozora i vratima s izlazom na terase. Od središnjeg prostora te dvorane su odijeljene raskošno oblikovanim stupovljem s tri prolaza. Središnji volumen jednakih stranica nad kojim je osmerostrana kupola poduprt je u sva četiri ugla tornjevima. Na tlocrtu su upisane i namjene prostora. Središnji je namijenjen skulpturama, obje dvorane slikarstvu, a mala dvorana, odvojena zidom s vratima, nacrtima i crtežima. Iz vestibula se lijevo ulazi u sobu nazvanu loža (za osoblje i okupljanje uzvanika) gdje je i portir, a desno u garderobu gdje su odvojeni toalet i pisoar. U tornjevima, u uglovima kvadrata, južno su u dva manja pretprostora dimnjaci za loženje, u većim su stubišta za sobe u mezaninu nad ulazom, a u sjevernim su izbe za poslužitelja i rekvizite. Trokuti s unutarnje strane kvadrata služe za ventilaciju prostora u u kupoli. U nacrt su upisane i osnovne mjere (sl. 2). ${ }^{7}$

Izvedbeni tlocrt je modificiran i pojednostavnjen. Nema terasa, prozora na dvoranama, stupovlja s ravnim nadvo- jima između dvorana, a u kutovima je po jedna izba bez manjeg ulaznog pretprostora. Promijenjena je i koncepcija zidanih konstrukcija. Olovkom su prekrižene obodne tanke dvostruke stijene i upisani presjeci zasnovani na modularnim veličinama opeke $30 \times 15 \mathrm{~cm}(\mathrm{sl} .3){ }^{8}$

Uspoređujući sačuvane nacrte presjeka i glavnog pročelja (sl. 4, 5), ${ }^{9}$ koji s opisanim tlocrtom čine cjelinu i dio su natječajnog rada, možemo govoriti i o konceptu arhitekture i oblikovanju pročelja paviljona. Evidentna je kompozicija volumena oko središnje vertikalne osi. Pročelja četiriju istaknutih volumena, triju dvorana i vestibula završena su trokutastim zabatima - timpanima. Plohe zidova pročelja raščlanjene su pilastrima na mjestima vertikala stupova čelične konstrukcije i imaju statičku funkciju podupiranja, kao i visoki piloni na svim vanjskim uglovima dvorana i vestibula. Središnju kvadratnu dvoranu natkriva osmerostrana ostakljena kupola polukružnog presjeka na zidanom tamburu, dvorane dvovodni zastakljeni krovovi, a prednji i stražnji rizalit pokriveni su limom. Na vrhu kupole je lanterna na kvadratnoj bazi završena krunom sv. Stjepana, prvog mađarskog kralja. I u projektu i u izvedbi osmerokutne kupole samo su duže stranice ostakljene, dok su četiri kraće stranice obložene limenim pokrovom, što nije uobičajeno rješenje za potpuno osvjetljenje prostora kupolom. Na donjoj strani kupola 


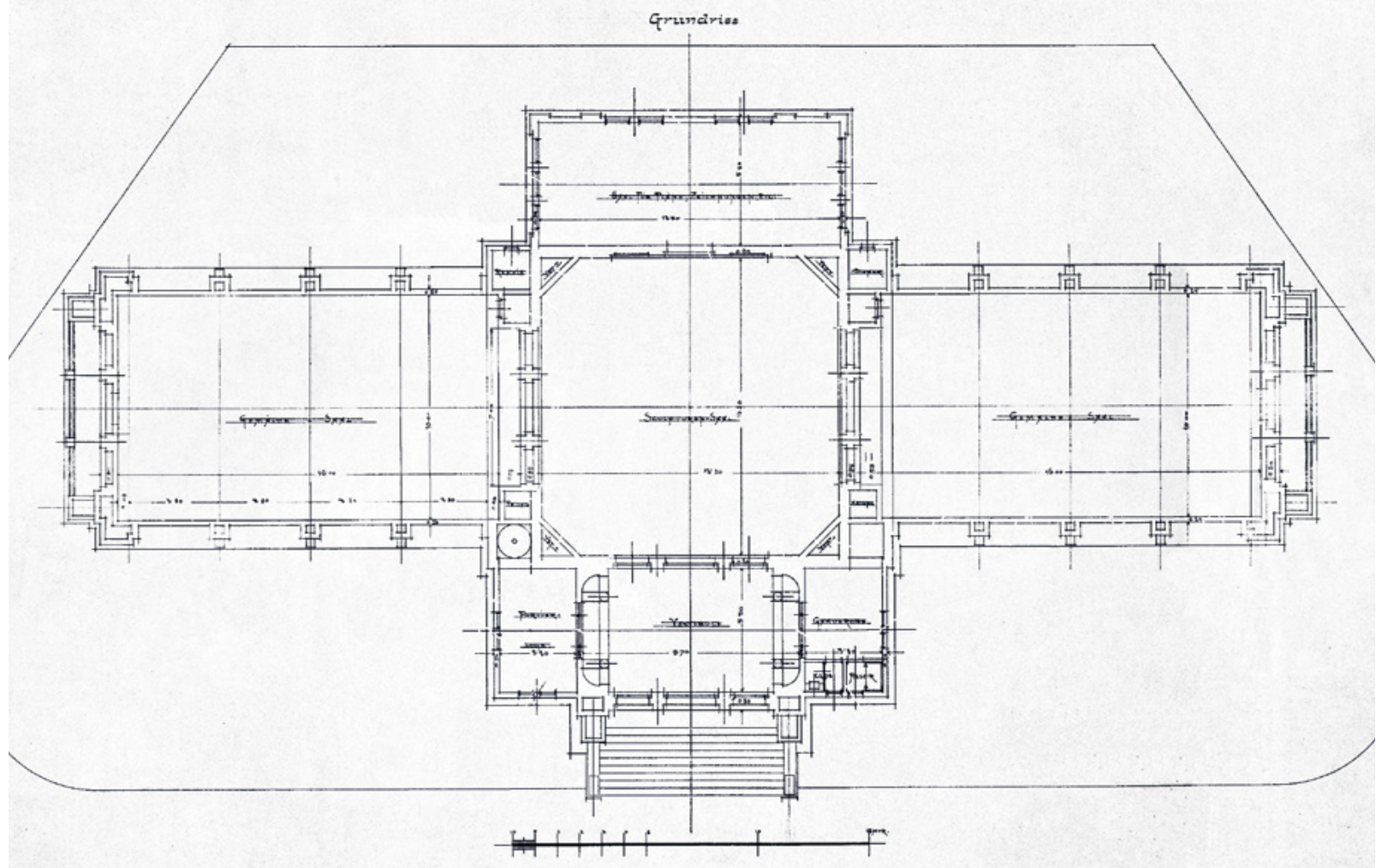

2. Korb i Giergl, projekt Paviljona za poviest i umjetnost, tlocrt, 1895. (HR DAZG, Gradsko poglavarstvo, Građevni odsjek, sign. 222) Korb and Giergl, project of the History and Art Pavilion, floor plan, 1895 (State Archives in Zagreb, City of Zagreb, Construction Department, sign. 222)

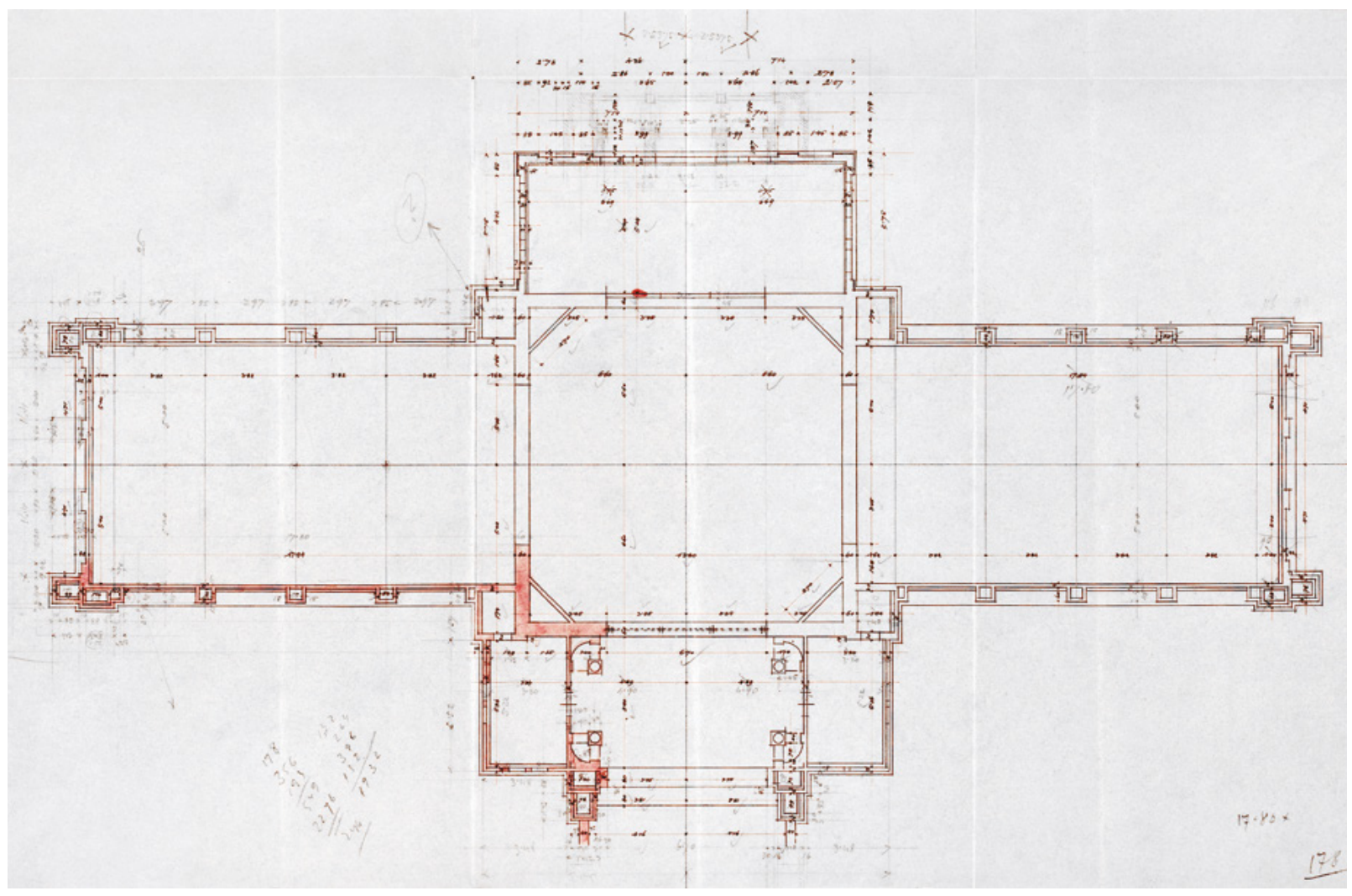

3. Korb i Giergl, projekt Paviljona za poviest i umjetnost, tlocrt za izvedbu, 1895. (HR DAZG)

Korb and Griegl, project of the History and Art Pavilion, working floor plan, 1895 (State Archives in Zagreb) 


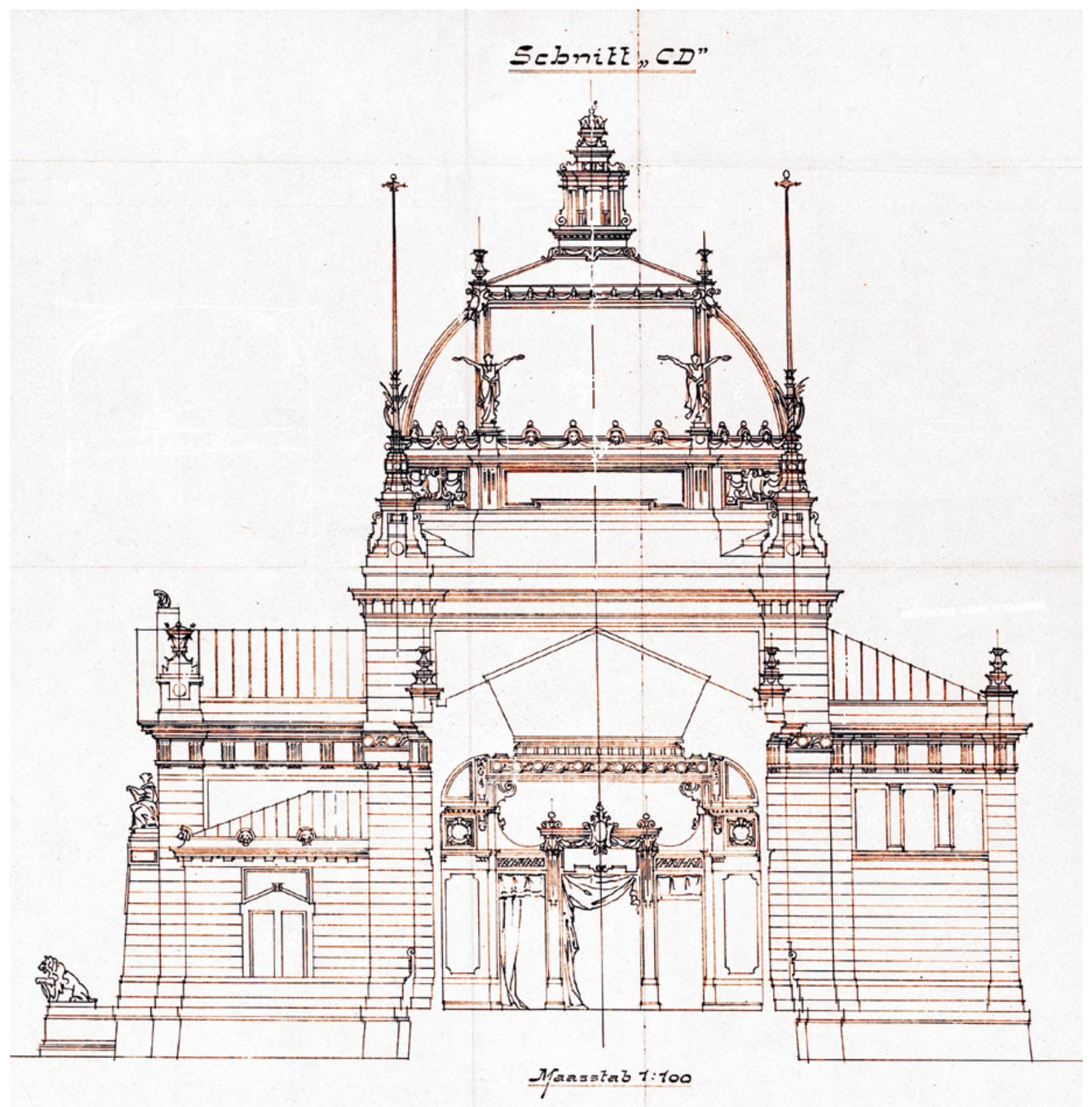

4. Korb i Giergl, Paviljon za poviest i umjetnost, presjek 1895. (HR DAZG)

Korb and Griegl, History and Art Pavilion, cross section, 1895 (State Archives in Zagreb)

je završena vijencem nad tamburom s nizom maskerona lavljih glava. Nacionalni simboli Trojedne Kraljevine nisu aplicirani na pročelja, već su postavljeni na jarbole na uglovima središnjeg volumena. Grbovi su ovješeni na štitove, a hrvatske zastave vijorile su pri vrhu. Postavu trobojnica uvjetovao je Vlaho Bukovac sudjelovanjem hrvatskih umjetnika na Milenijskoj izložbi. Portal trodijelnog glavnog ulaza istaknut je plitkim reljefima ženskih likova hermama na međustupcima i bogato profiliranom rešetkom u nadsvjetlu. Na nadvoju portala u gornjem je redu natpis „Umjetnički paviljon“ (u nacrtima glavnog pročelja na tom je mjestu natpis na mađarskom „Horvat-Slavon Orsag kiallitasa“, a na tamburu latinski „Ars Longa Vita
Brevis“). Prilazno stubište u vestibul, koji je izdignut oko 1,2 m od tla, izvedeno je između pilona sa skulpturama na vrhu, a ne prema projektu, gdje je ucrtano omeđeno zidovima sa skulpturama lavova. U konačnici, može se reći da je projektirani koncept oblikovanja historicističke arhitekture, uz neka pojednostavnjenja, zadržan i u izvedbi (sl. 6, 8). ${ }^{10}$

Unutrašnjost paviljona uredili su Vlaho Bukovac, Robert Frangeš Mihanović i Bela Čikoš-Sesija, u skladu s određenim namjenama dvorana. Iz fotografija interijera vidljiva je obrada ploha." Ispod ostakljenog stropa dvorana ovješen je baldahin, a podgledi obodnih greda oslikani su kazetama. Parapeti zidova obloženi su nabranim 


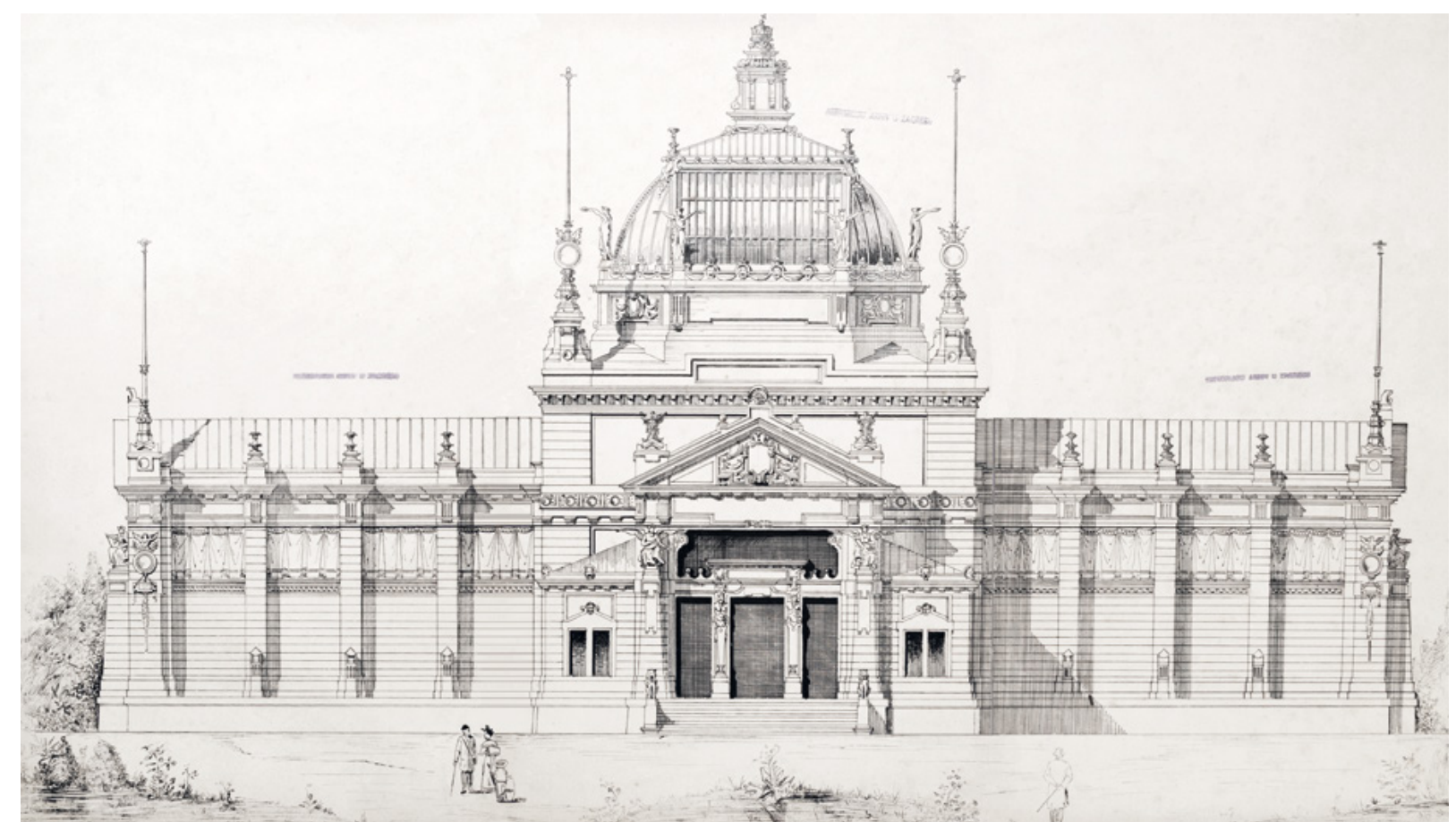

5. Korb i Giergl, Paviljon za poviest i umjetnost, glavno pročelje, 1895. (HR DAZG) Korb and Griegl, History and Art Pavilion, main front, 1895 (State Archives in Zagreb)

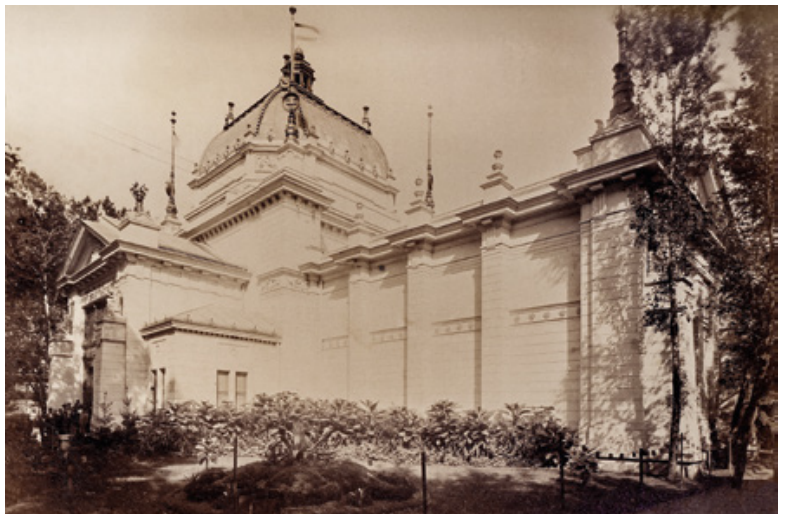

6. Paviljon za poviest i umjetnost s jugoistoka 1896. (HR DAZG) History and Art Pavilion from the southeast, 1896 (State Archives in Zagreb)

tkaninama i ukrašeni draperijom u obliku girlanda. $\mathrm{Na}$ daščanim podovima prostrti su tepisi. Namještaj je izrađen u Zagrebu. Ravnatelj Državnog arhiva Ivan Bojničić i tajnik Društva umjetnosti priredio je izložbu povijesnog odjela, izloživši arhivalije i blago crkvenih riznica (sl. 7). Na natječaju za izradu čelične konstrukcije paviljona odabrana je, kako izvješćuju Narodne novine od 11. svibnja 1895., tvrtka Danubius-Schoenichen-Hartmann, dioničko društvo za gradnju brodova i strojeva iz Budimpešte, koja daje 112,85 tona konstrukcije, s rokom montaže od sedam mjeseci u Budimpešti i tri mjeseca u Zagrebu. ${ }^{12}$ Već nakon mjesec dana, 15. lipnja 1895., tvrtka je dovršila nacrte konstrukcije ${ }^{13}$ koji slijede prihvaćeni arhitekton-

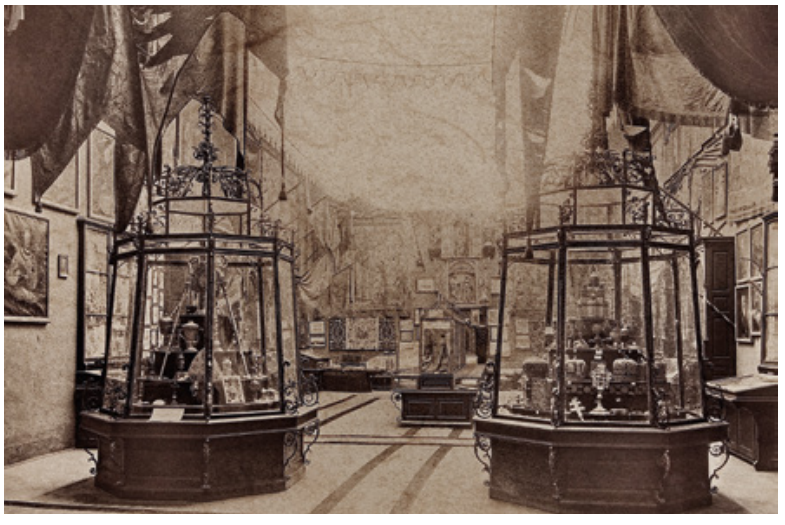

7. Istočna dvorana paviljona, Historička izložba, 1896. (HR DAZG, fond 135, sign. 22099)

East hall of the Pavilion, History Exhibition, 1896 (State Archives in Zagreb, fond 135, sign. 22099)

ski projekt. Međutim, uvidom u izvedeno stanje krovnih konstrukcija paviljona u Zagrebu, a i prema nalazima čeličnih elemenata stupova i greda u zidovima prilikom recentne obnove, evidentno je da su sheme prikazane projektom Danubiusa pri montaži promijenjene. Krovne rešetke dvorana u projektu imaju vertikalne štapove povezane dijagonalama, ali su izvedene kao niz kosih štapova. Oslonjene su na vertikalne stupove ugrađene $u$ zidove, $u$ krilima na razmaku od 3,82 m, visine 7,95 m (sl. 22a). ${ }^{14}$

\section{Umjetnički paviljon u Zagrebu 1896. - 1898. godine}

Za Gradski dom umjetnosti odabrana je lokacija južno od Kemijskog laboratorija, na sjevernoj strani Trga Franje 


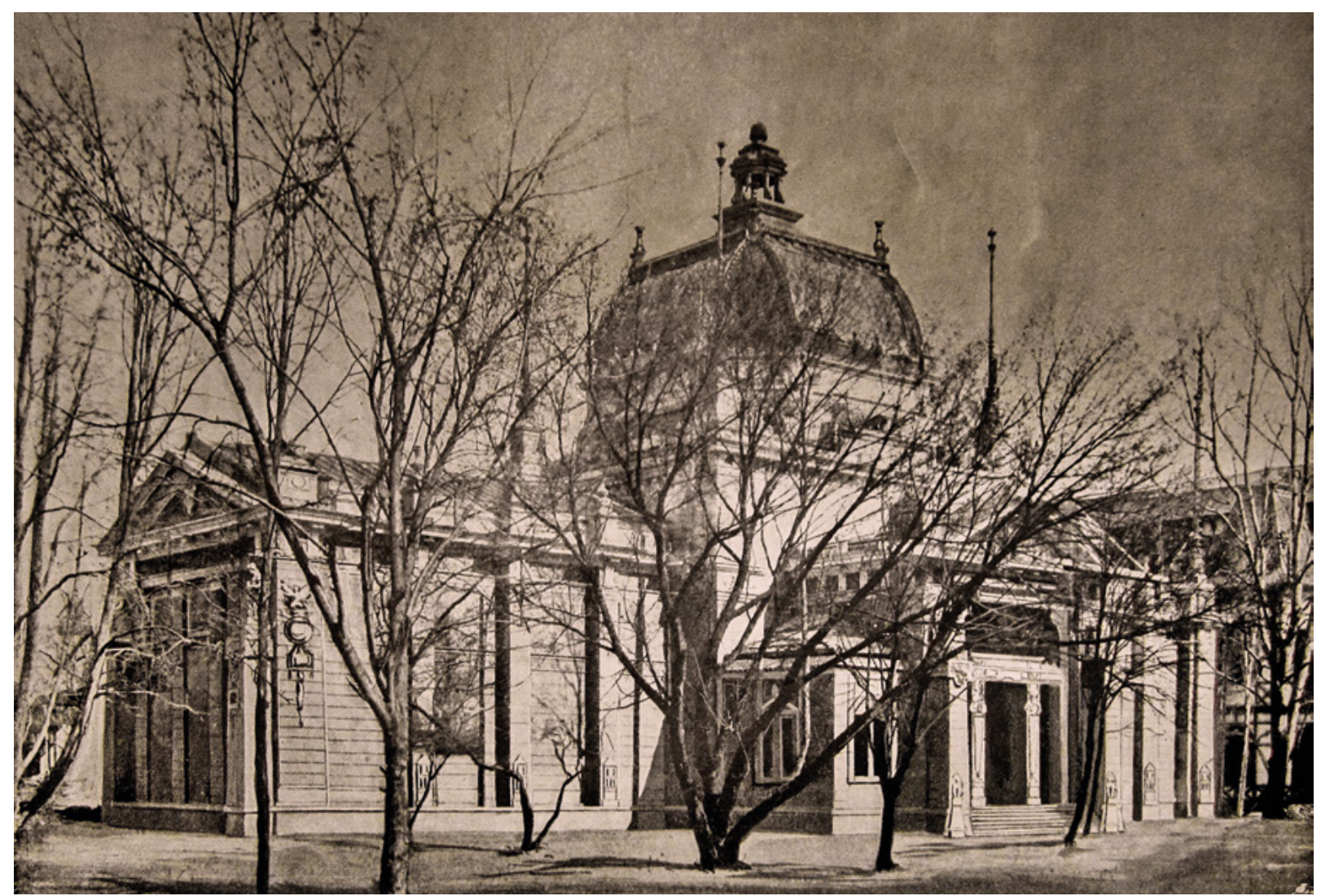

8. Paviljon za Poviest i umjetnost s jugozapada 1896., (dokumentacija M. Perušić) History and Art Pavilion from the southwest, 1896 (Documentation M. Perušić)

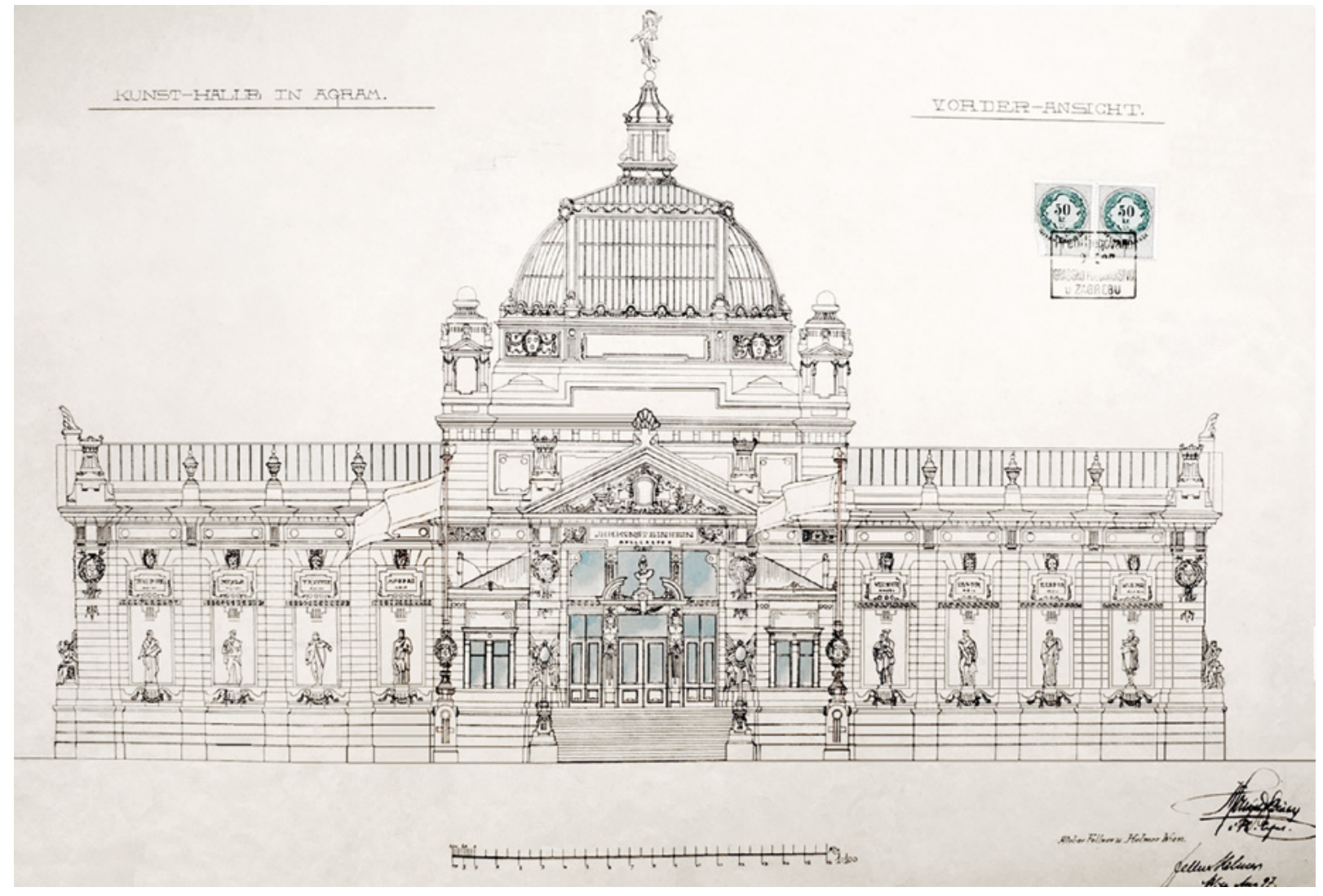

9. Fellner i Helmer, projekt Umjetničkog paviljona, 1897., sjeverno pročelje (HR DAZG)

Fellner and Helmer, project for the Art Pavilion, 1897, north front (State Archives in Zagreb) 


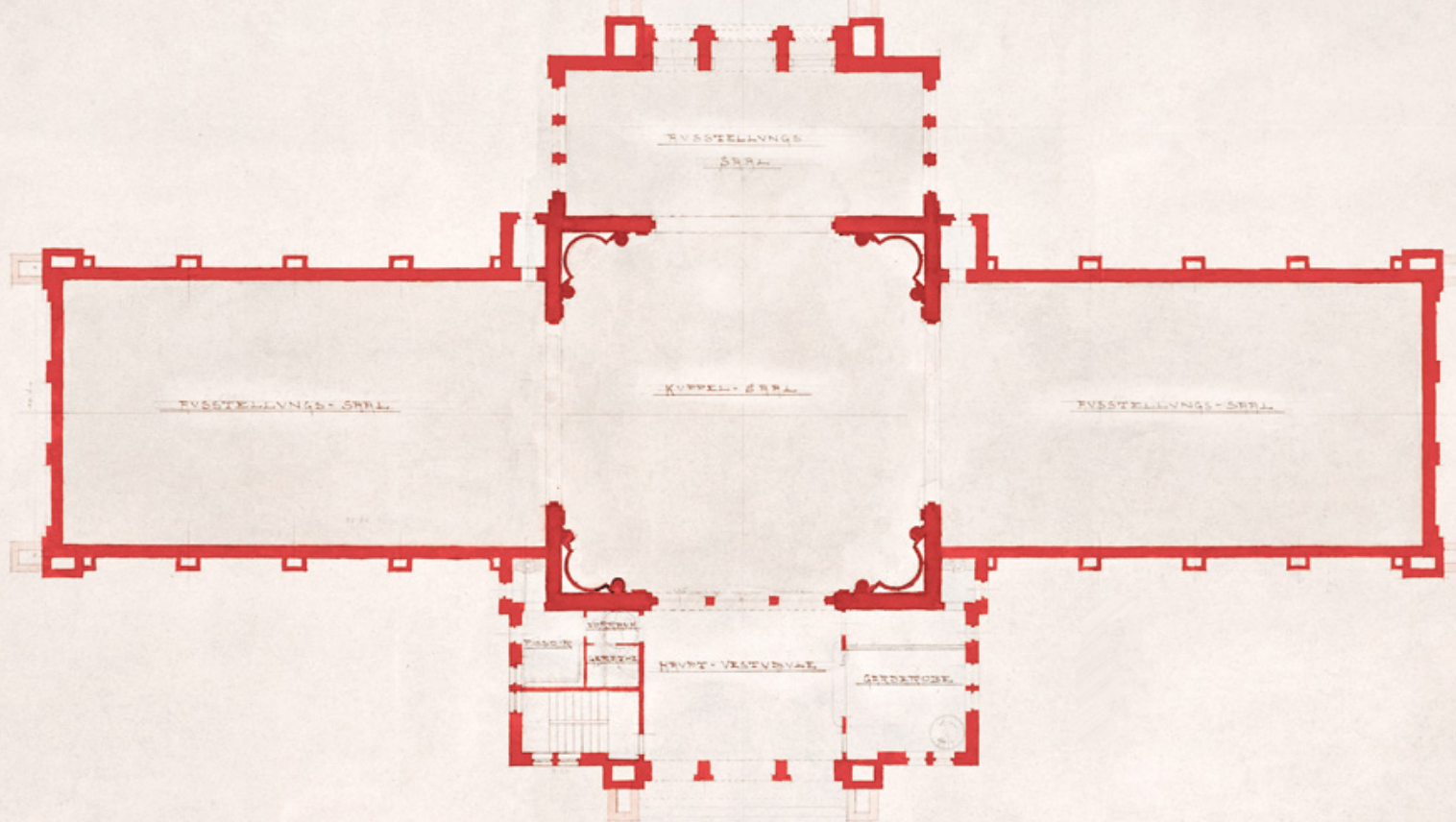

10. Fellner i Helmer, tlocrt gornjeg prizemlja za izvedbu, 1897. (HR DAZG)

Fellner and Helmer, working plan of the upper ground floor, 1897 (State Archives in Zagreb)

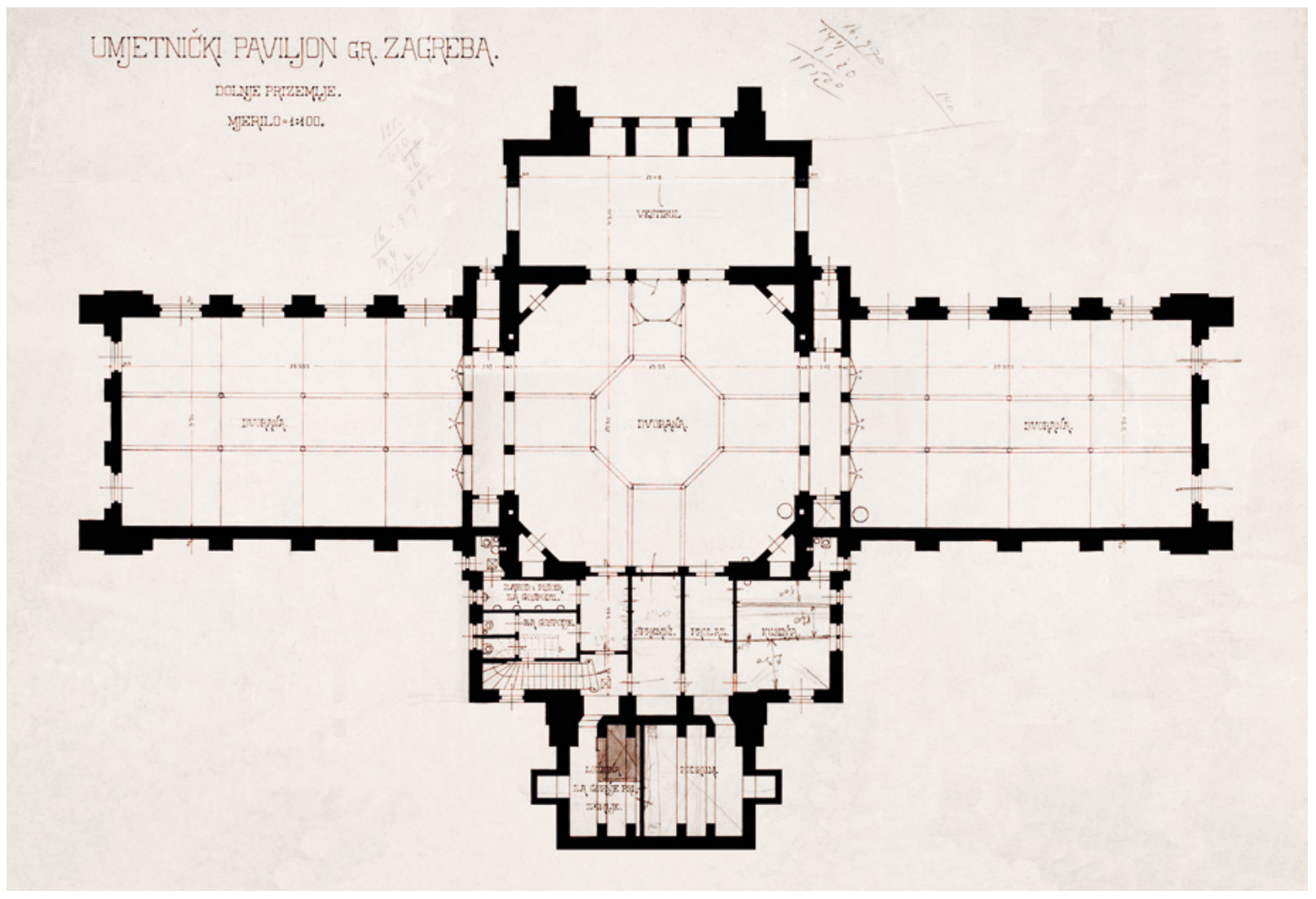

11. Fellner i Helmer, tlocrt donjeg prizemlja, izvedeno stanje, 1897. (HR DAZG)

Fellner and Helmer, plan of the lower ground floor, actual situation, 1897 (State Archives in Zagreb) 


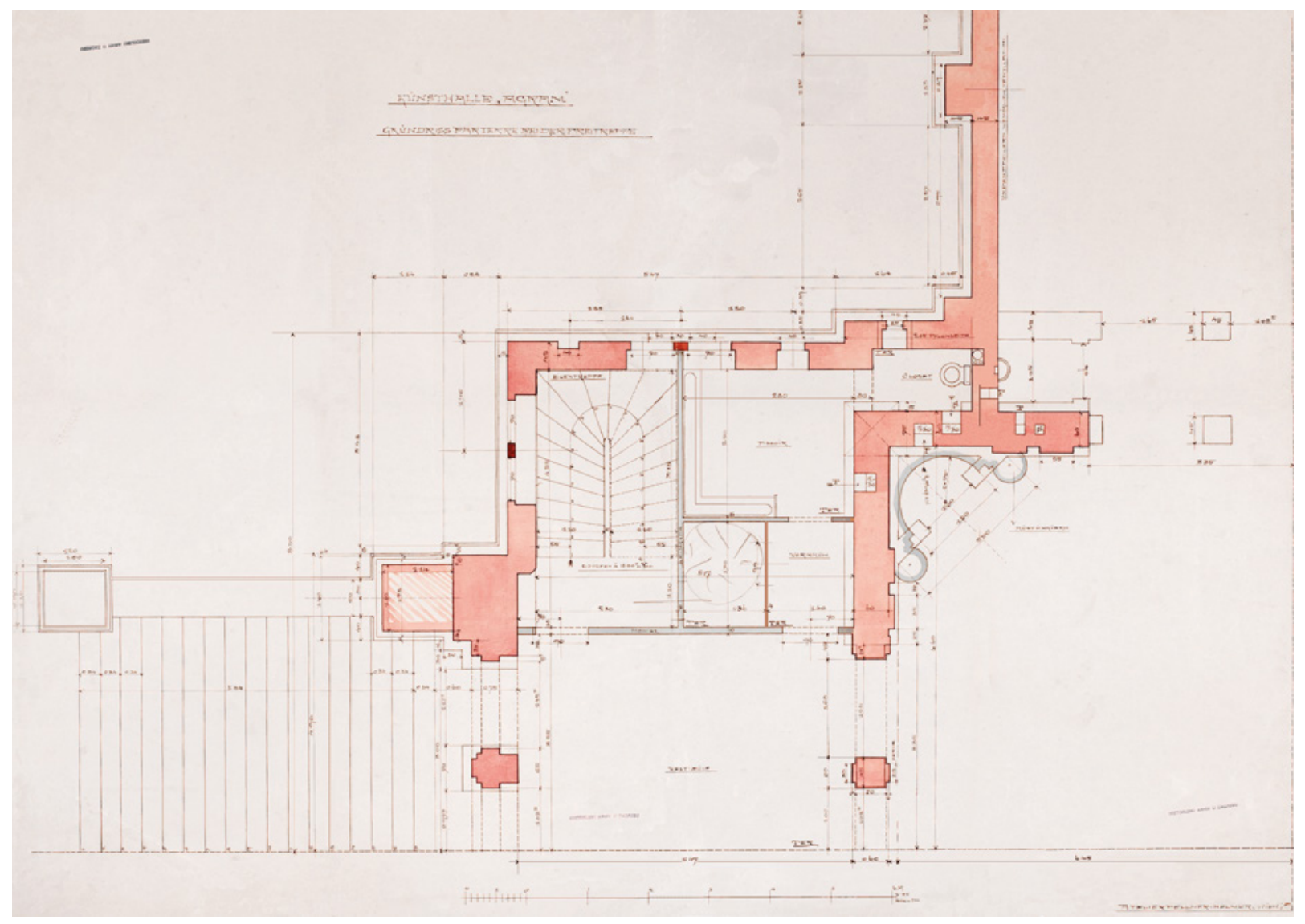

12. Fellner i Helmer, tlocrt dijela gornjeg prizemlja uz prilazno stubište, 1897. (HR DAZG)

Fellner and Helmer, plan of the portion the upper ground floor adjacent to the entrance staircase, 1897 (State Archives in Zagreb)

Josipa, u skladu sa suvremenim planovima razvoja grada, prema kojima je na tako istaknutom mjestu bila predviđena reprezentativna građevina. Iz istih razloga poseban je odbor 5. srpnja 1897. predložio Gradskoj skupštini da se arhitektonski projekt povjeri uglednom bečkom atelijeru Fellnera i Helmera, prema čijem je projektu u Zagrebu 1895. bilo izvedeno kazalište. ${ }^{15}$ Čini se da je predviđeni vrlo kratak rok izrade bio poštovan jer je na nacrtu „prednjeg“ pročelja, kako je nazvana sjeverna fasada s glavnim ulazom, ispod parafa arhitekata upisano „aug. 97. ${ }^{\text {“16 }}$

Arhitekti Ferdinand Fellner (1847. - 1916.) i Hermann Helmer (1849. - 1919.) bili su ograničeni u kreaciji već određenom strukturom i konstrukcijom građevine, a onda i temeljima koji su već bili izvedeni. Budući da je perivoj na južnoj strani bio definiran na razini prirodne savske ravnice, zbog razlike u visinama bilo je moguće izvesti donju etažu paviljona. Ta je gradnja zemljanih i betonskih radova izrade temelja već u rujnu 1896. dodijeljena građevinskom poduzetništvu Emila Eisnera i Adolfa Ehrlicha. Budući da je tvrtka Danubius bila odabrana za izradu i montažu čelične konstrukcije, a projekt je izradila još u lipnju 1895., ti su nacrti korišteni u izvedbi. Osnovni parametri za projektiranje zgrade bili su, dakle, zadani mjerama geometrije željezne konstrukcije koja je obzidana zidovima od opeke. Puni pilastri postavljeni su uz vertikalne čelične stupove kao ojačanja. Dvovodni krovovi dvorana iznad rešetki završeni su timpanima s bogatim skulptoralnim ukrasom.

Sačuvani su detaljni nacrti u kojima je ucrtana i kotirana sva arhitektonska plastika pročelja, ${ }^{17}$ koja je znatno programski razrađenija i bogatija od rješenja na Milenijskoj izložbi u Budimpešti. Razabire se i velik odmak od ideje Korba i Giergla u projektiranju ostakljenja svih osam stranica kupole, bez limenih dijelova na četiri kraće stranice. Na vrhu lanterne umjesto krune sv. Stjepana postavljena je skulptura Apolona u tunici s lovorovim vijencem, zaštitnika muza (Muzàgèta). Prema tada uobičajenom arhitektonskom obrascu, na uglovima podnožja kupole, gdje su bili jarboli, kreirani su visoki četverostrani volumeni s profiliranim oblogama, $u$ funkciji ukruta kupole s kanalima dimnjaka i ventilacija. Visoki piloni sniženi su u razinu podnožja, ali su na njima zadržane skulpture alegorije umjetnosti. Stubište izdignuto od tla $2,5 \mathrm{~m}$ zbog donje etaže, istaknuto je izvan objekta, ima bočne zidove i pri dnu kandelabre za osvjetljivanje pristupa. Arhitektonska plastika na pročeljima i kupoli također se razlikuje. Više figuralne plastike ima $u$ dubokom reljefu nego u plitkom. U poljima između pilastara zidova dvorana predviđene su skulpture hrvatskih velikana s natpisnim pločama u obliku tabulae ansate. Grbovi Trojedne Kraljevi- 


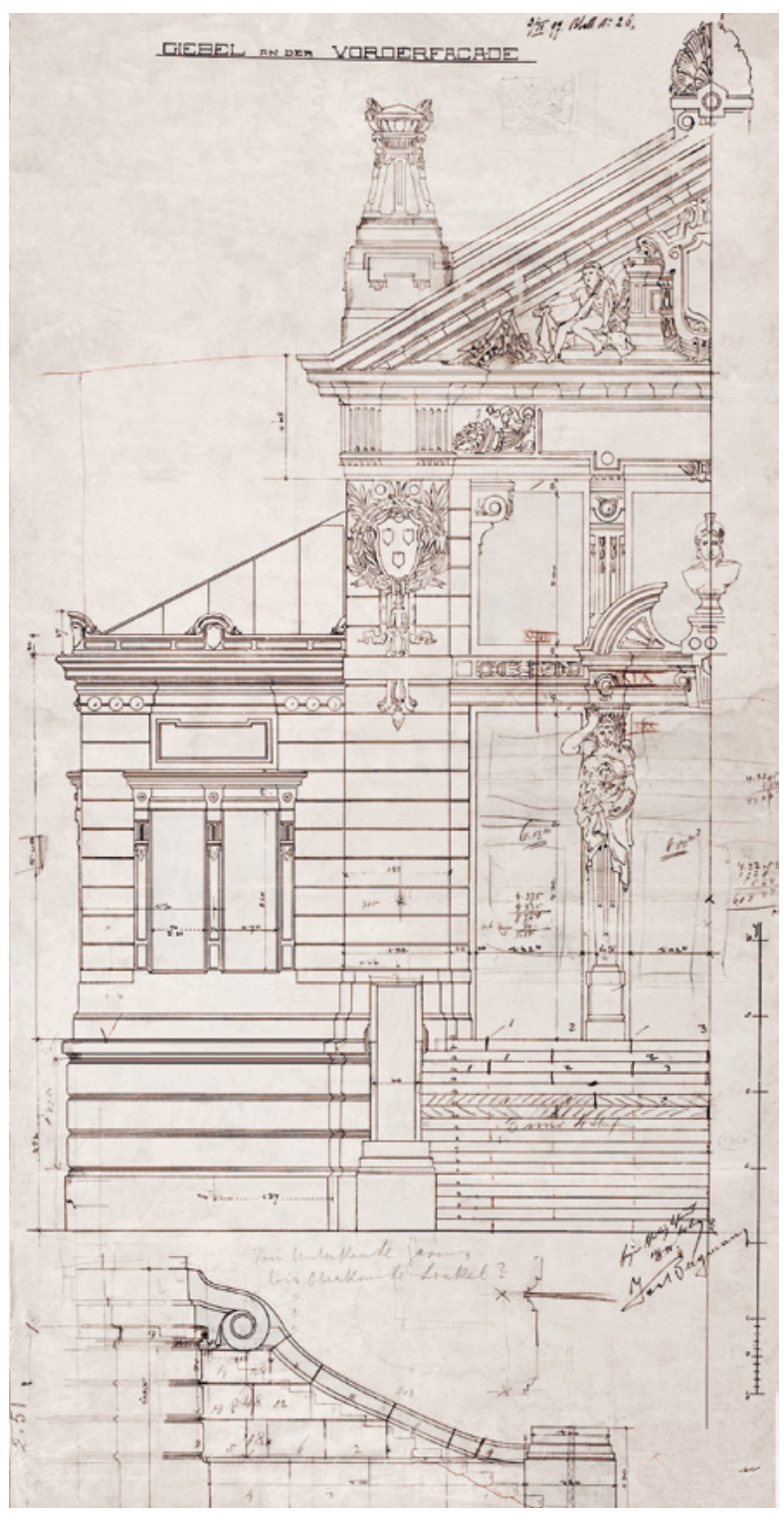

13. Fellner i Helmer, izvedbeni detalji sjevernog pročelja, 1897. (HR DAZG)

Fellner and Helmer, working plan details of the north front, 1897 (State Archives in Zagreb)

ne aplicirani su na uglovne pilastre. Posebno je istaknuta obrada ulaznog portala s bistom Atene u prelomljenom luku nadvoja i stupci herma između triju vrata (sl. 9). U prvom tlocrtu projektanata rješenje prizemlja još nije bilo definirano, posebno prostori uz vestibul i komunikacije s razizemljem i mezaninom, gdje su olovkom ucrtavana moguća rješenja dispozicije sadržaja. Dvorane na kraćim stranama imaju po tri prozora, a po dva stupa formiraju tri prolaza u srednju i malu dvoranu. ${ }^{18} \mathrm{U}$ drugom tlocrtu dvojbe su razriješene te je $u$ istočnom dijelu ulaznoga rizalita uz sanitarije za muškarce projektirano dvokrako metalno stubište koje je povezivalo gornje i donje prizemlje, kako se dvije etaže nazivaju u nacrtima, i sobu u mezaninu. ${ }^{19} \mathrm{U}$ zapadnom dijelu uz pročelje je garderoba i kružno zavojito stubište za mezanin, smješteno pred

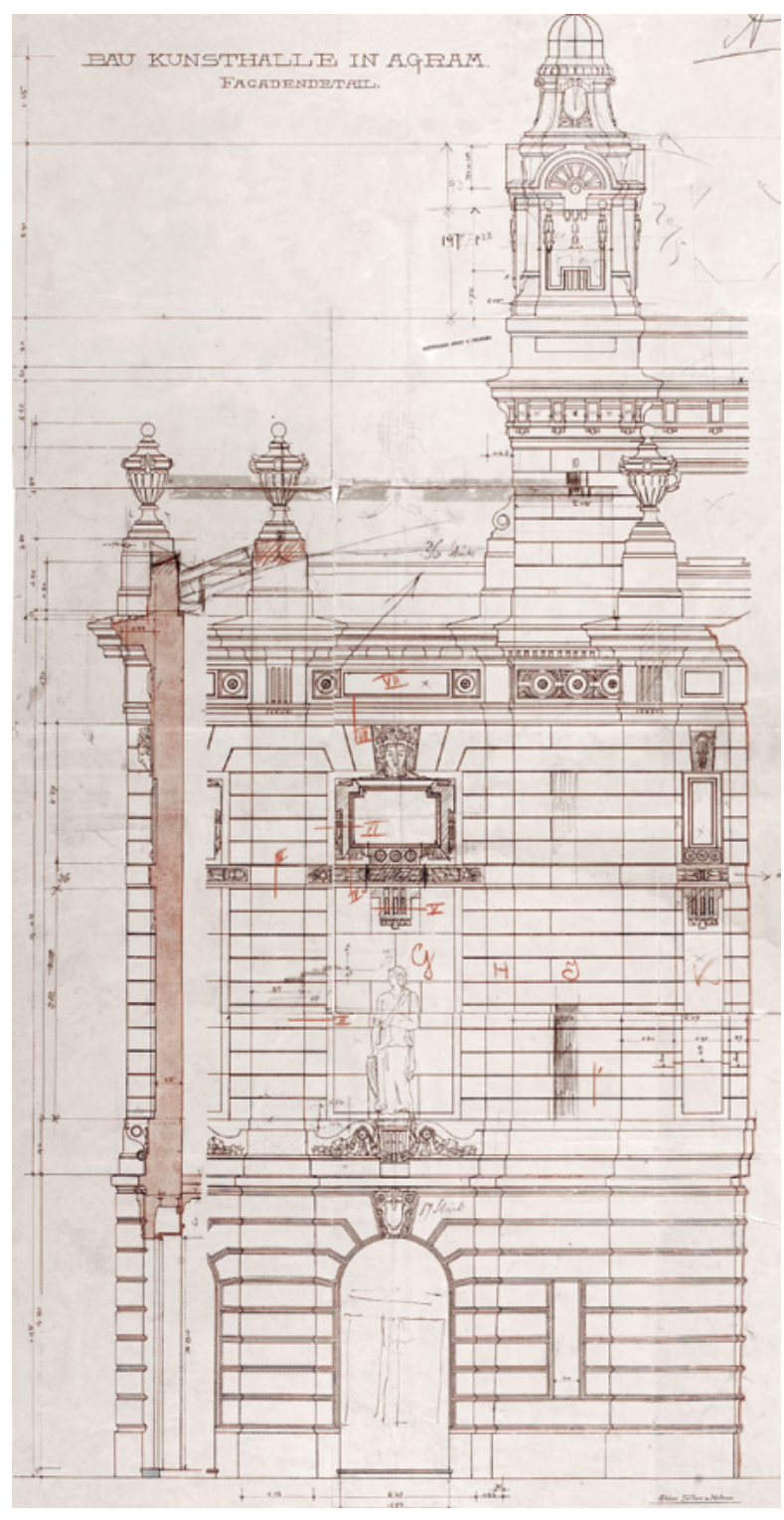

14. Fellner i Helmer, izvedbeni detalji južnog pročelja, 1897. (HR DAZG)

Fellner and Helmer, working plan details of the south front, 1897 (State Archives in Zagreb)

prozor, a u stražnjem dijelu je hodnik i toalet za žene. Na dvoranama više nema prozora. Tlocrtna površina gornjeg prizemlja paviljona obuhvaća $680 \mathrm{~m}^{2}$ (sl. 10).

U donje prizemlje (razizemlje s južne strane) prilazi se kroz otvoreni trijem vestibul i preko vjetrobrana ulazi u srednju dvoranu i bočne dvorane odvojene dvostrukim stupovljem i vratima. Na sjevernoj strani ispod rizalita su pomoćne prostorije, desno kuhinja za restoran, koji je prihodom trebao služiti održavanju zgrade, sa sanitarijama za osoblje, a lijevo su sanitarije za goste i stubište u gornje prizemlje. Ispod vanjskog stubišta u podrumu je smještena kotlovnica za grijanje izložbenih prostora i spremišta. Za grijanje dvorana $u$ donjoj etaži postavljene su velike peći, a dvije su, 6 × 6 × 12 kaljeva, bile u prostoru do 1986. godine (sl. 11). 


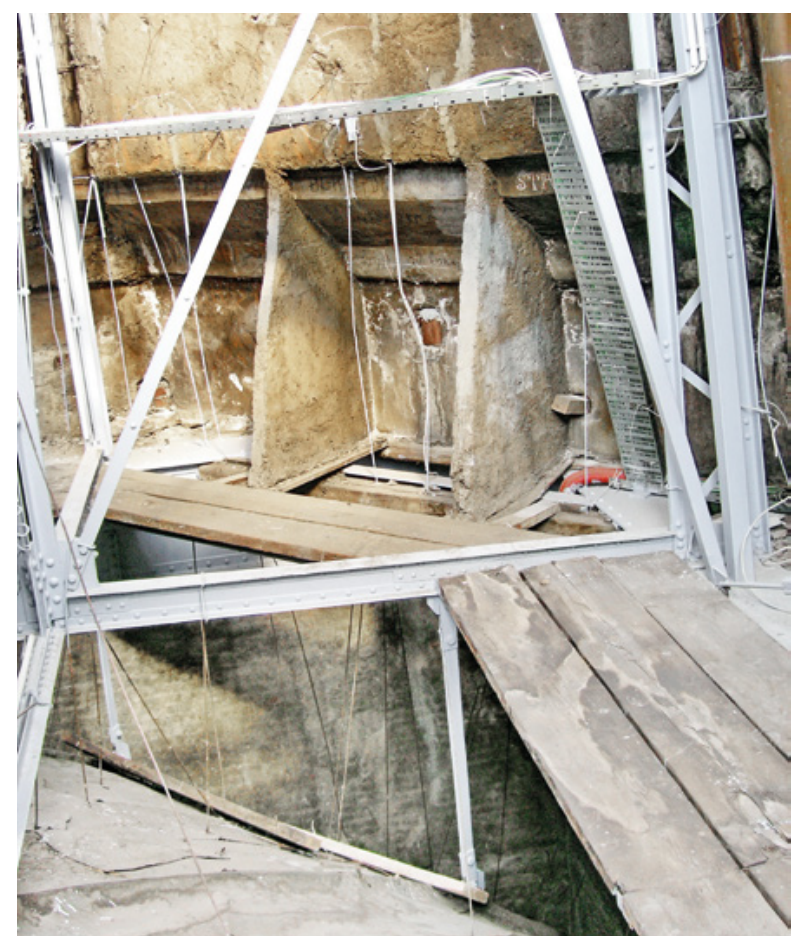

15. Tambur kupole iznutra, stanje 2006. (fototeka GZZSKIP-a, snimio M. Perušić)

Drum of the dome from the interior, situation in 2006 (Photo Archive of the City Institute for the Protection of Monuments of Culture and Nature, photo by M. Perušić)

Do kraja kolovoza i početka rujna 1897. atelijer Fellnera i Helmera dovršio je i detaljne nacrte rekonstrukcije Umjetničkog paviljona. ${ }^{20}$ Zanimljiv je kolorirani tlocrt detalja vestibula i stubišta, ${ }^{21}$ crtan u mjerilu 1:25 (sl. 12), dok su prethodni nacrti u mjerilu 1:100. Na tom je tlocrtu naznačen i kut zida istočne i srednje dvorane s nišom za skulpturu. Nacrt je detaljno kotiran i opisan, osim namjene prostorija, obrade materijala i podova ima i natpise na pojedinim karakterističnim elementima: vanjsko stubište, monier zidovi i lučni dijelovi stropova debljine $10 \mathrm{~cm}$ i gipsane pregrade debljine $7 \mathrm{~cm}$, plinske peći (sic), razne obloge, opšavi i drugo. Ucrtani su vanjski i unutarnji dvojni pilastri, niše za instalacije i dimnjaci. Uz pune zidane pilastre dvorana stoji opaska: „Ako je moguće uz stup izvesti ventilaciju“. Naime $u$ prethodno prikazanim tlocrtima projekata i Korba i Griegla i Helmera i Fellnera na mjestima stupova konstrukcije $u$ zidu debljine $45 \mathrm{~cm}$, izvana su istaknuti pilastri zidani opekom debljine $15 \mathrm{~cm}$, u sredini je šupljina, ali u tom detalju tlocrta pilastri su ispunjeni, što je statički povoljnije. Opaska ukazuje na to da su se na tim mjestima ipak željeli zadržati kanali za odzračivanje prostora dvorana. Prikazano je i okruglo stubište za prilaz istočnoj sobi u mezaninu za koje je, za Zagreb, Danubius izradio detaljni nacrt s brojem i dimenzijama stuba. Na zapadnoj strani takvo stubište za mezanin, umjesto pred prozor, ugrađeno je u prostor tornja. Detaljni nacrti dijelova sjevernog i južnog proče-

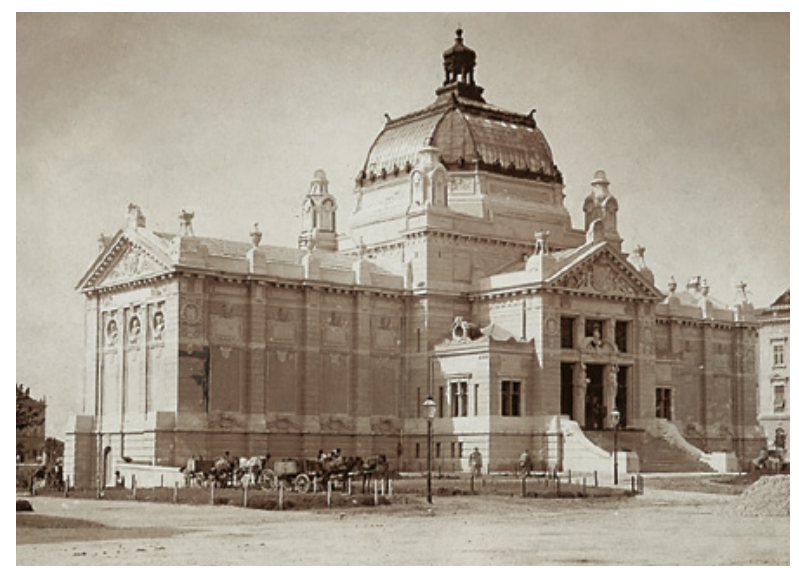

16. Umjetnički paviljon 1898., fotografija Juliusa Hühna (fototeka MGZ-a)

Art Pavilion in 1898, photograph by Julius Hühn (Photo Archive of the Zagreb City Museum)

lja bili su na gradilištu i poslužili za izvođenje, uz ovjeru arhitekta Bergmana koji je nadzirao radove (glavni nadzornik bio je inž. Milan Lenuci). ${ }^{22}$

Dijelovi pročelja razrađeni su na više listova u pogledu i presjeku. Niz proračuna i bilješki na njima unesen je olovkom. Nacrti su izrađeni u velikom mjerilu pa je moguće analizirati i odabrani povijesni građevni red i proporcijske sheme. Vidljivi su i detalji ukrasa, akroteriji, žare, rog obilja, figure uz grb u timpanu i herme sa ženskim likovima, alegorijama slikarstva i kiparstva s atributima (sl. 13) i obrade ploha dimnjaka, vaze na krovnom vijencu, poprsje u zaglavnom kamenu iznad tabula ansata, postolja skulptura u poljima i drugo (sl. 14). U interijeru su donje vidljive ostakljene plohe podgleda stropa imale oslikane bordure u dvoranama i u srednjoj dvorani obrub s hrvatskim trobojnicama. I za taj segment slikanja na način vitraja sačuvane su skice projektanata. Takav način razrade projektne dokumentacije omogućio je vrlo preciznu izvedbu radova, za koje je odabrana tada najkvalitetnija tvrtka u Zagrebu - Julia Deutscha i Lavoslava Hönigsberga.

Iako je kupola projektirana s ostakljenjem na svim stranicama, izvedena je s limenim dijelovima na kraćim stranicama na daščanoj oplati s podložnim gredama. Taj je dio, kao i lanterna s kuglom na vrhu, prenesen iz Budimpešte uz čelične konstrukcije. Skulptura Apolona iznad kugle i one predviđene na pilonima i poljima dvorana nisu realizirane. Kupola je sastavljena od lučnih rešetki prostorno povezanih i oslonjenih na osmerostrani tambur, koji leži na kvadratnom središnjem volumenu. Konstrukcija tambura kupole izvedena je od tankostijenih armiranobetonskih nosača - monier stijenki koje se pojavljuju i na drugim mjestima zgrade, što je vrlo rana primjena takvog statičkog elementa $u$ gradu (sl. 15). Strop podruma konstruiran je od opeka u blagom luku koje su oslonjene na čelične traverze $u$ rasponima rastera nosive konstrukcije stupova. Gradnja je dovršena 7. lipnja, a Pa- 


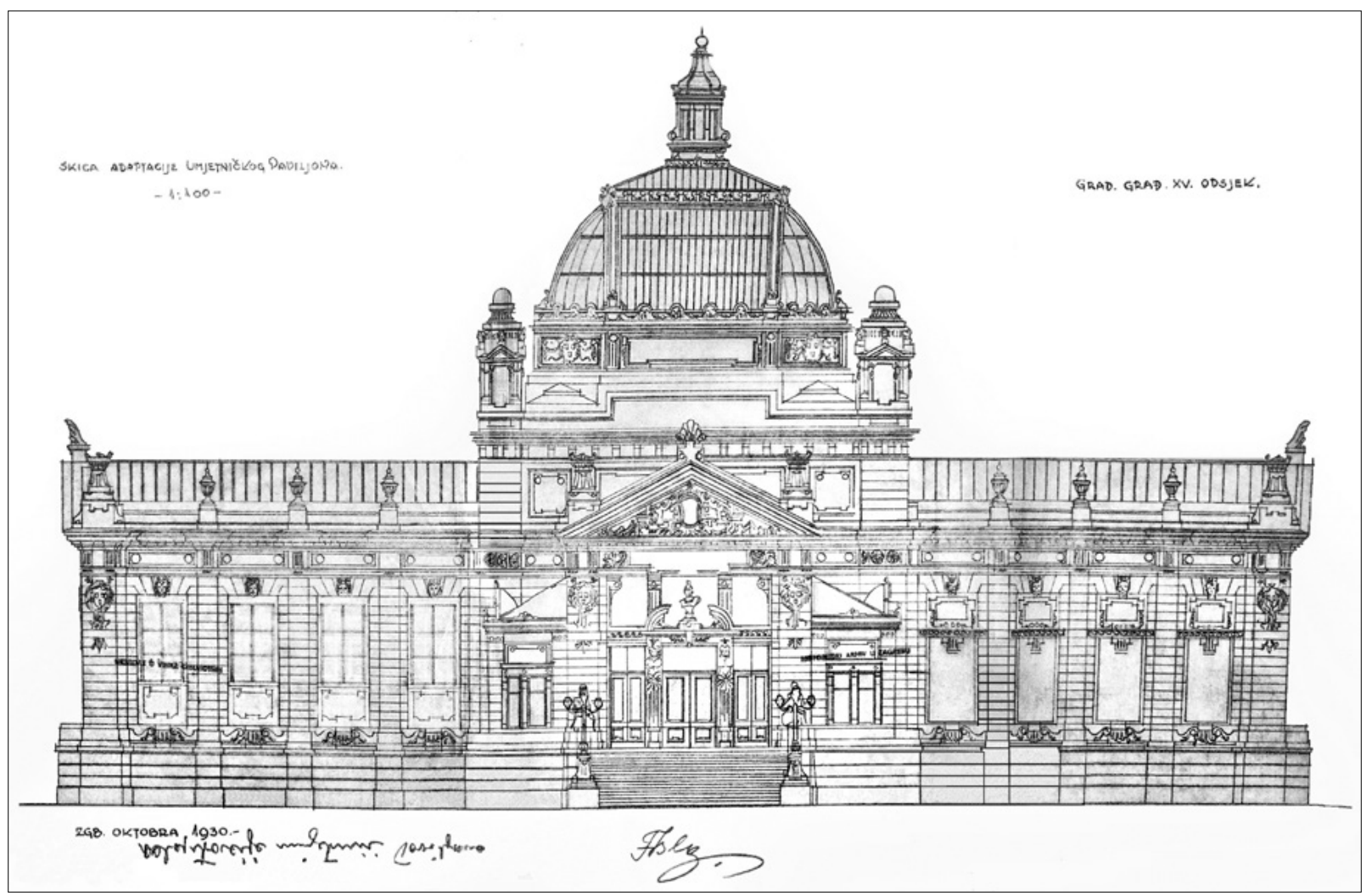

17. Gradski građevni XV. odsjek, adaptacija paviljona, sjeverno pročelje, 1930. (HR DAZG)

City Building Department XV, Pavilion renovation, north front, 1930 (State Archives in Zagreb)

viljon je otvoren 15. prosinca 1898. izložbom Hrvatskog salona Društva umjetnosti. Iste godine fotografirao ga je Julius Hühn (sl. 16). Trošak gradnje prema Spomenici gradonačelnika Adolfa Mošinskog iznosio je 260.875 kruna i 12 filira. ${ }^{23}$ Suvremeni tisak na dan otvorenja izložbe opisao je interijer i ocijenio zgradu. ${ }^{24}$ Detaljan prikaz Umjetničkog paviljona i sudionika gradnje donio je 1900. Josip Chvala i naveo namjenu srednje dvorane o kojoj je poslije bilo prijepora: „Ovaj je prostor, budući da ima služiti za representancu i koncerte, najbogatije urešen.“25 Skulpture alegorija umjetnosti koje su projektirane i izvedene na pilonima u Budimpešti, a prikazane i u projektu Fellnera i Helmera, trebali su u Zagrebu raditi hrvatski kipari. Međutim samo su na vrhu ogradnoga zida prilaznog stubišta 1901. postavljene skulpture alegorije kiparstva i slikarstva Rudolfa Valdeca, koji je radio skice i za reljefe u timpanima. Stubište su osvjetljavala dva trostruka kandelabra iz radionice Božidara Devidéa s okruglim staklom, koji su sačuvani do danas.

Društvo umjetnosti dobilo je paviljon na korištenje prve tri godine. Tražilo je u donjem prizemlju prostoriju za svoj rad, uredovnicu, knjižnicu i čitaonicu, ali to nije odobreno jer je ta etaža iznajmljena za restoran i kavanu. U umjetničkim se krugovima i krugovima u oporbi vladi i banu iz političkih razloga, o zgradi i posebno interijeru odmah sudilo vrlo kritički. Zamjeralo se historicističkom ruhu arhitekture i raskošnoj obradi unutrašnjosti, gdje umjetnički izlošci nisu mogli biti dovoljno istaknuti. ${ }^{26}$ U četiri desetljeća o paviljonu su kritički pisali, nakon otvorenja: Vlaho Bukovac, ${ }^{27}$ Antun Gustav Matoš $1908 .{ }^{28}$ i Gjuro Szabo 1941., ${ }^{29}$ a o nefunkcionalnosti zgrade i problemima sa zagrijavanjem pisao je 1936 . Ivo Šrepel. ${ }^{30} \mathrm{U}$ međuvremenu, zgrada paviljona je zbog neodržavanja propadala, a krovovi dvorana i kupola često su bili sanirani zbog prodiranja vode..$^{31}$

\section{Preoblikovanje paviljona 1938. - 1939.}

Mišljenje umjetnika o nemogućnosti izlaganja u prostoru paviljona, jer zbog raskošno obrađenih ploha njihova djela ne mogu doći do punog izražaja, kao i zbog i uskrate dobivanja prostorija za Društvo umjetnosti, rezultiralo je odlukom o potrebi gradnje novog umjetničkog paviljona. Inicijativa je prihvaćena 1925. i razrađena 1930. godine. Dom likovnih umjetnosti je, prema ideji Ivana Meštrovića građen od 1934. do 1938. na Trgu N (današnji Trg žrtava fašizma). Zato je $u$ više navrata planirana prenamjena zgrade Umjetničkog paviljona, u kojem su se već u prvoj četvrtini 20. stoljeća u donjem prizemlju izmjenjivali korisnici. Nakon izložbe Tisućgodišnjice hrvatskog kraljevstva 1925. koju je u obje etaže postavio Ljubo Babić, ${ }^{32}$ donja je dodijeljena Muzeju grada Zagreba, a postav je otvoren 14 . kolovoza 1926. Sveučilište je 1921. predložilo da se gornja izložbena etaža preuredi u čitaonicu Sveučilišne biblioteke. Za prenamjenu paviljona, XV. Gradski građevni odsjek 


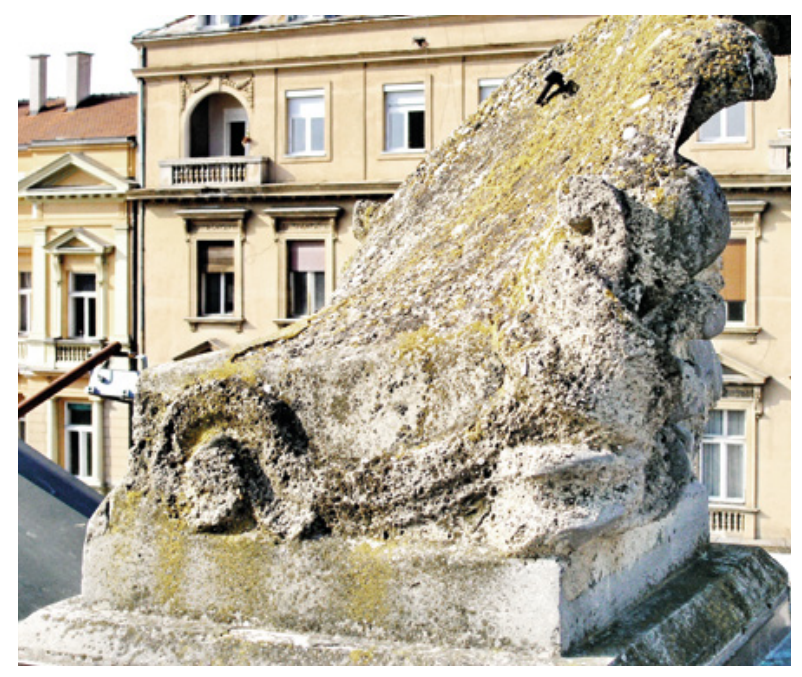

18. Akroterij na krovu zapadne dvorane, stanje 2007. (snimio M. Perušić)

Acroterion on the roof over the west hall, situation in 2007 (photo by M. Perušić)

1930. nacrtao je skicu adaptacije pročelja s visokim prozorima u poljima između pilastara istočne dvorane (sl. 17). Nešto kasnije, 1938. arhitekt Ignjat Fischer izradio je novi projekt za Gradsku knjižnicu. ${ }^{33}$ Osvjetljavanje čitaonice, na gornjoj etaži, predvidio je samo s ostakljenog stropa, bez prozora na zidovima, ali ih je predvidio u donjoj etaži, spremištu knjiga, na sjevernoj, ulaznoj strani, gdje je za niz prozora probio dvostruki zid izveden zbog izolacija od vlage i kamenu oblogu podnožja. U visokom podkupolnom prostoru postavio je galerije s policama na četiri nivoa. Do takve realizacije i prenamjene paviljona ipak nije došlo, ali je te godine počela građevinska sanacija zgrade zbog dotrajalosti. Višedesetljetno negativno mišljenje dijela struke o paviljonu imalo je učinak i paviljon je $u$ to vrijeme najviše izgubio na izvornom oblikovanju pročelja. Gradski građevni odsjek Gradskog poglavarstva, nakon dvojbi bi li Umjetnički paviljon trebalo obnoviti, srušiti ili prenamijeniti, pripremio je građevinsku dokumentaciju za obnovu pročelja i u lipnju 1938. raspisan je natječaj. U rujnu je poduzetnik Stanko Horvat počeo s radovima. Sačuvana je pogodba, troškovnici, obračuni graditeljskih i obrtničkih radova ${ }^{34}$ i nacrt, ${ }^{35}$ na kojem su označeni dijelovi arhitektonske plastike koju treba ukloniti. Precrtani su vertikalni elementi iznad krovova, velike lanterne-tornjići uz kupolu, žare nad uglovnim pilastrima i vaze uz timpane rizalita ulaza. Na krovnom vijencu, $u$ plohi friza sve kružne forme u rizalitima i poljima između pilastara, simboli Trojedne Kraljevine, grbovi u reljefnim vijencima na uglovnim pilastrima, a u zidnim poljima maskeroni iznad tabula ansata i ploče triglifa ispod njih. Sjeverni i južni rizalit najviše su izgubili od izvornog oblikovanja. Skinuta je bogata skulptoralna plastika portala ulaza, poprsje Atene u prelomljenom luku i herme na međustupcima. Sa zaglavnih kamena niša svih otvora u razizemlju južnog pročelja reljefi s glavama i niz drugih manjih elemenata arhitektonske plastike (kako je prikazano na sl. 22).

Opseg obnove vidljiv je iz spomenutog troškovnika i obračuna s prilogom dokaznice mjera. Radovi su obuhvaćali i ponovno bušenje zida podruma debljine $60 \mathrm{~cm}$ za deset prozora na sjevernoj strani, ali ni tada to nije izvedeno. Razdvojeni su radovi obnove arhitektonske plastike u žbuci koje treba izvesti jedan izvođač od one od drugih materijala, većinom od cinčanog lima koje je trebao organizirati Grad s drugim izvođačem, ali to nije ostvareno. Visoki tornjevi uz kupolu su demontirani, a završeci dimnjaka i ventilacija dobili su završetke u obliku plitkih vaza od lijevanog betona s kulir obradom. Na isti su način i cinčane žare na uglovima vijenca krova dvorana zamijenjene akroterijima, koji su 2006 . zatečeni tako oštećeni da su izgubili prvotni oblik (sl. 18).

Popravak limarije koji je izvodila tvrtka Maruzzi, kao i 1898 ., sastojao se samo od saniranja lanterne i zamjene dotrajalog opšava, materijalom istovjetnim izvornom, sve od cinčanog lima. Limarija je zaštitno ličena olovnom Suboks bojom za željezo u tonu sličnom fasadi. Betonske akroterije i vaze ličene su uljanom bojom s posipom fine prašine od mramornog pijeska također u boji i materijalu nalik na žbuku pročelja. Dakle, boja pročelja je na svim elementima tada bila monokromna. Komisija na prvoj primopredaji radova u siječnju 1939. ustanovila je da ne udovoljavaju potpuno uvjetima pogodbe. Boja cijelog pročelja bila je nejednolika, na južnoj strani i kupoli bile su mrlje, a na zapadnoj strani dio žbuke se ljuštio. Te je radove pretežito vodio arhitekt Franjo Bahovec, zaposlenik Gradskog građevnog odsjeka, a odnosili su se na graditeljske, limarske i ličilačke radove.

\section{Promjene na zgradi 1945. - 2000. godine: pregradnje i popravci}

Organiziranje velikih izložbi pratila su ponekad oštećenja na zgradi prilikom manipulacije izlošcima. Radi izložbe Srednjovjekovna umjetnost naroda Jugoslavije 1951. demontirani su sa stubišta trostruki kandelabri izrađeni $u$ radionici Devidé i nisu vraćeni. Stoga se uključila služba zaštite i Zdenka Munk je u ime Konzervatorskog zavoda, početkom kolovoza 1953., konstatirala da su skinuti bez dozvole Zavoda. Tražila je od Gradske plinare da se vrate i postave, uz obrazloženje da su „potrebni zbog cjelovitosti dojma ulaza u Umjetnički paviljon“. Plinara je još u vrijeme obnove 1938. tražila da se rasvjeta plinom zamijeni električnom strujom. Tek je na ponovni zahtjev konzervatora, Odjel za građevinarstvo u listopadu 1953. naredio Gradskoj plinari da ih vrati, uz dopuštenje da se plin zamijeni strujom. ${ }^{36}$

Iduće, 1954. godine izrađen je nacrt stanja središnjeg prostora nakon postave trajnih obloga oko svih istaknutih dijelova srednje dvorane, radi zaklanjanja izvornih 


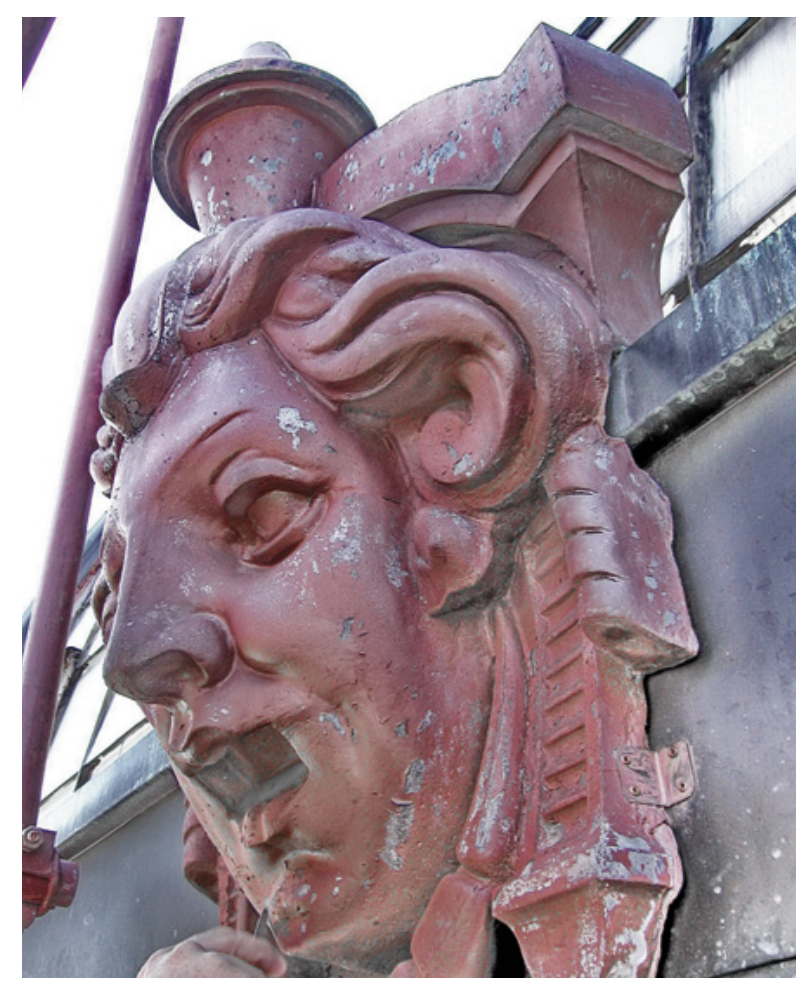

19. Maskeron na vijencu kupole, 2007. (fototeka GZZSKIP-a, snimila M. Gorianc Čumbrek)

Masqueron on the dome cornice, 2007 (Photo Archive of the City Institute for the Protection of Monuments of Culture and Nature, photo by M. Gorianc Čumbrek)

bogatih dekoracija, marmorizacija i pozlata, ovjeren žigom paviljona. ${ }^{37} \mathrm{Na}$ taj način je, sa zakašnjenjem od pedesetak godina od otvorenja paviljona, zahtjev umjetnika za neutralnom pozadinom, kako bi pogledi na izloške sa svih strana bili ujednačeni, ostvaren. Visoki panoi od tekstila na drvenoj konstrukciji postavljeni su oko prolaza $u$ srednji prostor, $u$ vestibulu i u sve tri dvorane, i to tako da su smanjene i prepolovljene širine otvora i prolaza. Uklonjeni su u kraćem vremenu, nakon trideset godina, nakon manjeg požara 1974., vjerojatno i zbog vraćanja izvorne namjene prostora za „representancu i koncerte“.

Tisak je povremeno izvještavao o stanju paviljona te je 1956 . napisano da je prethodne godine obnovljen dio kupole paviljona, ali da je najveći problem zagrijavanje izložbenog prostora, što je velika smetnja prilikom održavanja izložbi zimi jer sustav ne radi još od prije Prvog svjetskog rata, zbog velikog troška za ugljen. Novi sustav grijanja počeo se pripremati 1964. s kotlovnicom na mazut. Budući da je trebala biti blizu dimnjaka, odabran je prostor uz interno stubište, a sanitarije su dislocirane $u$ podrum ispod prilaznog stubišta. $U$ dvoranama, između nosača konstrukcije, zidovi dvorana su izdubljeni $16 \mathrm{~cm}$ i formirane su niše za lijevanoželjezne radijatore. Prilikom montaže oštećen je pod od višebojnog ukrasnog teraca i staklene prizme u podu središnje dvorane. ${ }^{38}$ Godine 1975 . izvedena je plinska kotlovnica.

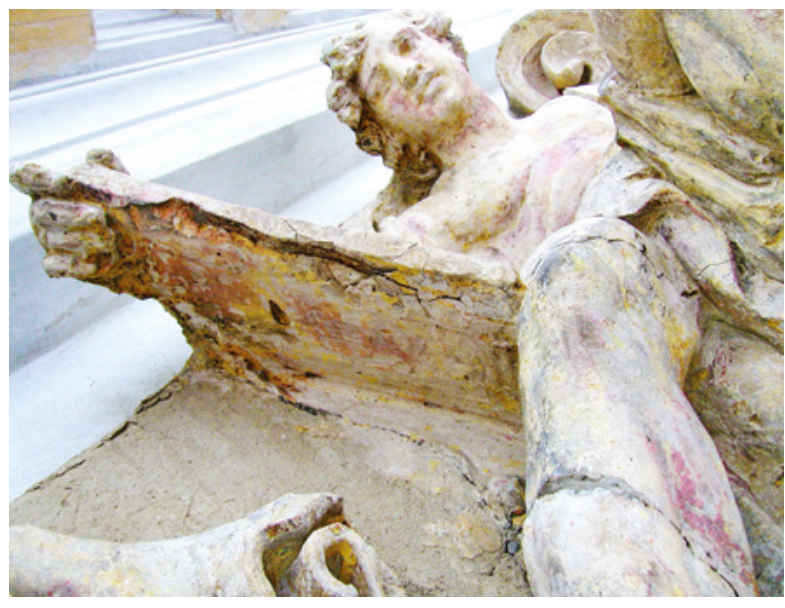

20. Reljef alegorije arhitekture, 2007. (snimio M. Perušić) Relief of the allegory of architecture, 2007 (photo by M. Perušić)

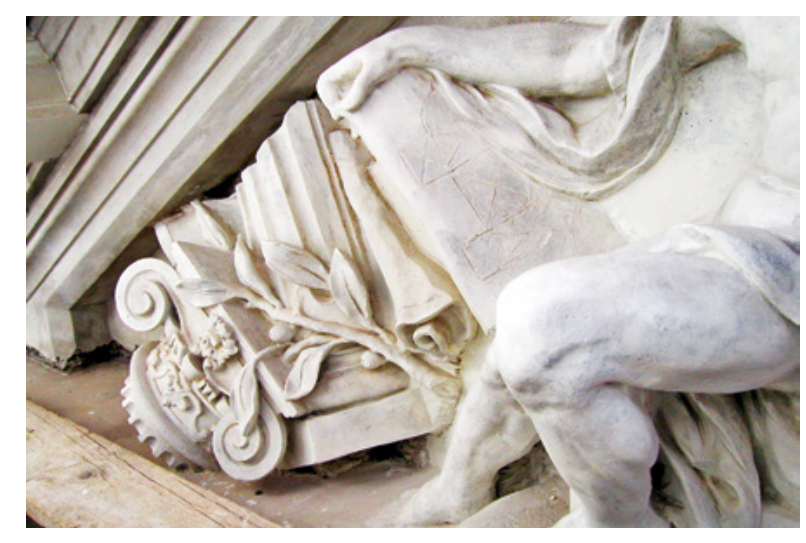

21. Reljef alegorije arhitekture, detalj s tlocrtom crkve na ploči, 2009. (snimio M. Perušić)

Relief of the allegory of architecture, detail with a church layout on a plate, 2009 (photo by M. Perušić)

Sljedeća veća intervencija poduzeta je 1968., kad je izvorni cinčani lim dijela krovne limarije i kupole zamijenjen pocinčanim. Ilustrativan je način uključenja ovlaštene konzervatorske službe, koja je Paviljon upisala u popis spomenika 1962., post festum. Izvođač Inženjering 23. travnja 1968. od Regionalnog zavoda za zaštitu spomenika kulture $u$ Zagrebu traži određivanje boje kao zaštitu od korozije za lim, budući da su radovi izvedeni. Tjedan dana poslije, 30. travnja, Zavod donosi rješenje i izdaje prethodnu dozvolu za obnovu krovne limarije i popravak „uz uvjete obnove limenih elemenata pokrova kupole zamjenom u cinčanom limu u profilu i plastici prema postojećim elementima. Na skulptorskim elementima $u$ limu potrebno je izvršiti pažljivi popravak bez oštećivanja... i ličenje starih limenih elemenata koji se ne zamjenjuju u mat naliču prema izboru predstavnika Zavoda“. ${ }^{39}$

U međuvremenu, 1966. u Paviljon su pozvani stručnjaci Restauratorskog zavoda Hrvatske. ${ }^{40}$ Pregledali su zgradu i sastavili zapisnik s očevida - promemoriju o stanju pokrova, pročelja i dekoracija unutrašnjosti i pri- 


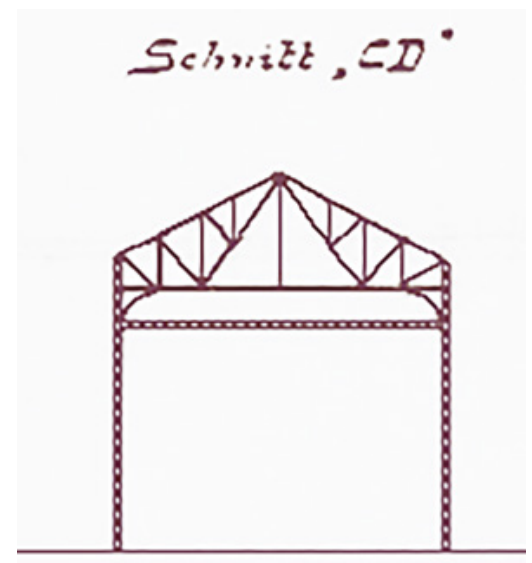

22a. Danubius, projekt konstrukcije, krovni vez dvorana, 15.6.1895. (HDA) Danubius, project of the construction of the roof truss in the halls, June 15th, 1895 (Croatian State Archive)

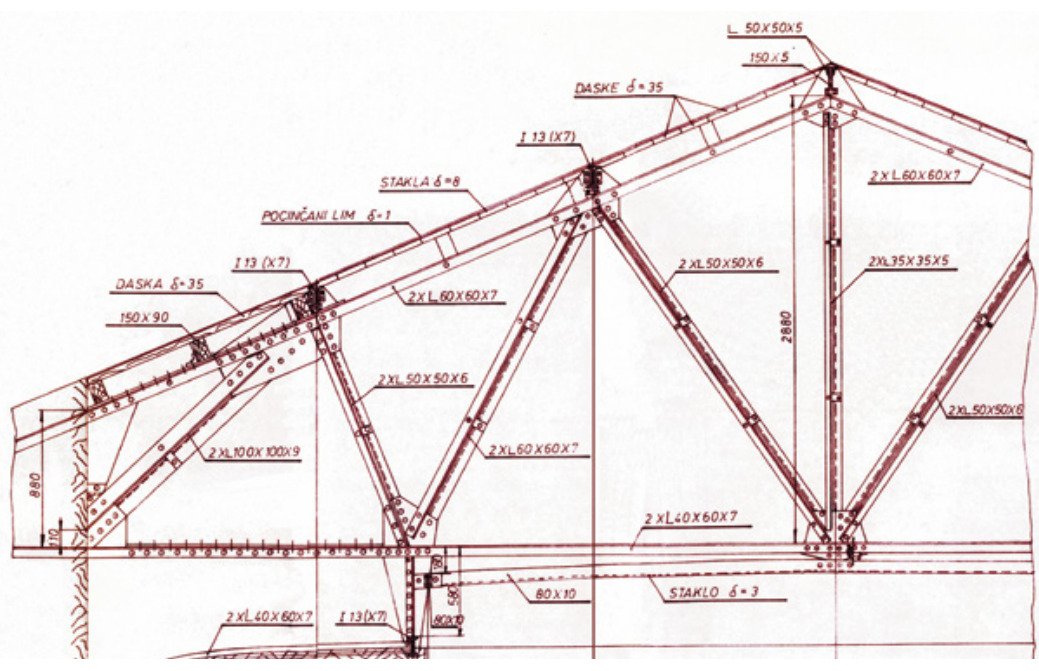

22b. Konstrukcija krovnog veza dvorana, Građevinski fakultet 1974. (Arhiva Umjetničkog paviljona)

Construction of the roof truss in the halls, Faculty of Civil Engineering, 1974 (Art Pavilion Archive) stupu obnovi. Zavod je 1974. pripremio koncept izrade projektne dokumentacije za obnovu pročelja i interijera i izradio aproksimativni troškovnik. Predviđeni su radovi sanacije postojeće pocinčane limarije s ličenjem (koja je izvedena 1968. i očito nije zamijenjena prema rješenju i uvjetima konzervatora) i na kupoli zamjena postojećeg lima s bakrenim, otucanje sve žbuke pročelja, obnova kipova, stuba, podnožja-sokla, postava mreža od mjedi na timpanima i drugo. U interijeru su stropovi dvorana imali prozirno staklo pa je predviđena zamjena, popravak stolarije i, zanimljivo, restitucija kipova u nišama srednje dvorane „adekvatnim“.

Godine 1977. predan je ponudbeni troškovnik izrade tehničke dokumentacije za obnovu Umjetničkog paviljona, a 1983. ponuda za obnovu interijera male dvorane. ${ }^{4{ }^{1}}$ Međutim, do suradnje s Restauratorskim zavodom Hrvatske nije došlo. ${ }^{42}$ Godine 1974 . ing. Branko Posavec iz IPB-a izradio je projekt rekonstrukcije nove rasvjete, a 1976. gromobranske instalacije; tada su prvi put shematski nacrtana nova pročelja nakon zahvata $1938 .{ }^{43}$ Zbog povećanja opterećenja rasvjetnim tijelima, na Građevinskom fakultetu inženjeri Kolar i Herceg izradili su kontrolni statički proračun krovnih vezača dvorana i kupole. Ustanovljeno je da i po tada važećim propisima udovoljavaju stabilnosti i da je moguće na predloženi način postaviti svjetiljke (sl. 22b).

U sklopu priprema za Univerzijadu '87. obnavljana su pročelja zgrada $u$ središtu Zagreba. Na Umjetničkom paviljonu izvedeni su u tri godine opsežni radovi na vanjštini i u interijeru. Tvrtka Plan izradila je projekte i nadzirala radove od 1984 . do 1987 . godine. ${ }^{44}$ Voditelj projekata i nadzora bio je Stjepan Banfić, arh., a odgovorni projektanti - arhitekti Darko Vlahović i Branko Vučinović. Nakon pregleda opisali su stanje zgrade. Pod razizemlja bio je od cementne glazure, a strop od lučnih svodova opeke poduprt u trećinama raspona čeličnim stupovima. Stubište za gornju etažu bilo je izvorno, od čelične konstrukcije sa stubama od keramičkih pločica. Sanitarije, namijenjene i restoranu, još su bile uz stubište na prvotno građenom mjestu. Naveli su da je plinsku kotlovnicu potrebno osuvremeniti. Budući da pročelja Paviljona 1898. nisu potpuno izvedena prema sačuvanom nacrtu bečkog atelijera, a izmijenjena su i u radovima 1938., nije postojao detaljni nacrt stvarnog stanja pa je Marijan Kadi, dipl. ing. geod., 1984. izradio fotogrametrijsku snimku svih pročelja. ${ }^{45}$ Radove je izvodila Zagrebgradnja u nekoliko faza, najprije 1984. sjeverno pročelje, 1985 . istočno i zapadno, 1986. južno i 1996. - 97. uređenje donje etaže s rampom za prilaz. ${ }^{46}$

Za restauraciju oslika unutrašnjosti Plan je zatražio ponude od RZH-a, ali je Zavod upozorio na to da su priloženi njihovi aproksimativni troškovnici iz 1974. i 1983. i da je potrebno izraditi izvedbenu dokumentaciju, ali to nije usvojeno. Ravnateljice Paviljona i RZH-a, prof. Lea Ukrainčik i Gabrijela Šaban, dipl. ing. arh, bile su u višegodišnjoj komunikaciji, a nakon što je vođenje obnove povjereno APZ Planu, uključen je i Stjepan Banfić, arh. ${ }^{47}$ Oslik interijera restaurirao je potom akad. slikar prof. Vladimir Pavlek, uz nadzor prof. Branka Lučića na čelu komisije nadležnog zavoda. ${ }^{4}$

Za projekte je Regionalni zavod za zaštitu spomenika 14. veljače 1985 . izdao rješenje. ${ }^{49}$ Predviđeno je i izvedeno otucanje sve žbuke s ravnih dijelova i profilacija, zamjena pocinčanog lima iz 1968. bakrenim. Nova produžno-cementna žbuka premazana je disperzivnom bojom na bazi akrilne smole (fasadeks). S takvim je pristupom bilo poteškoća u izvedbi radova. Na novu bakrenu limariju, koja je pojednostavnjenih formi i profilacija (lanter- 

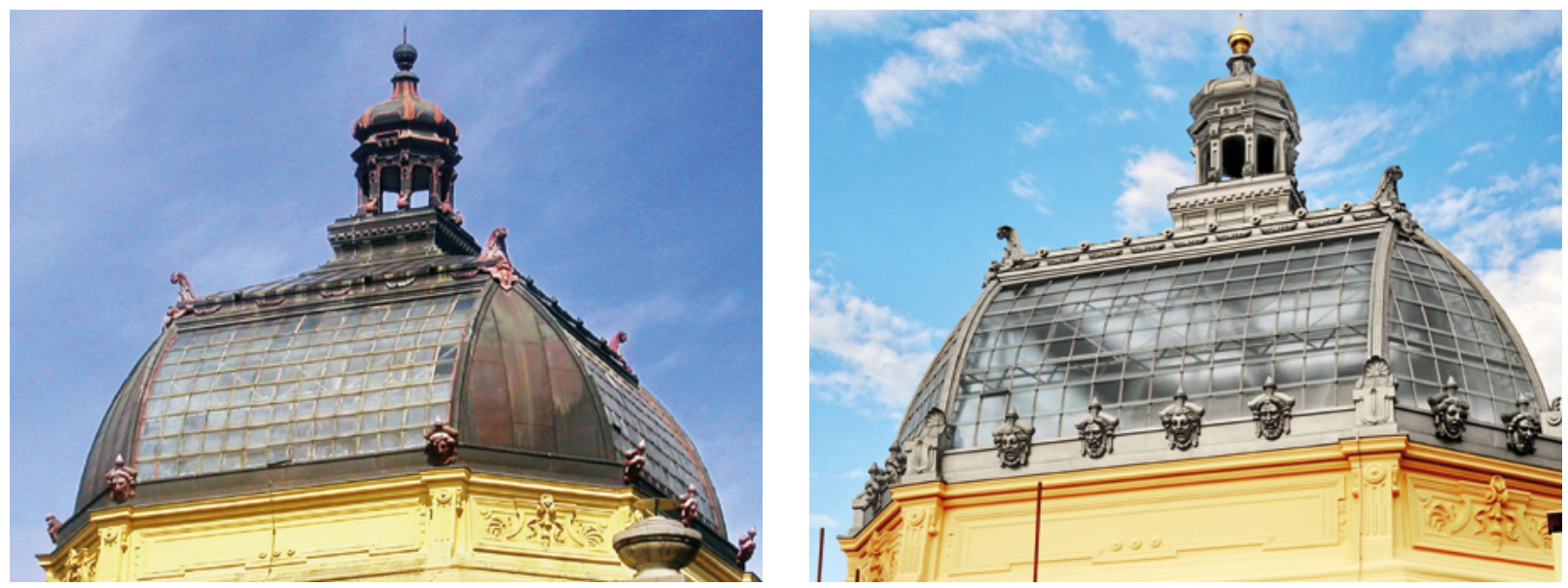

23.a, b Kupola paviljona prije radova, 2007. (snimila M. Gorianc Čumbrek) i nakon radova, 2010. (snimio M. Perušić)

Pavilion dome before conservation, 2007 (photo by M. Gorianc Čumbrek) and after conservation, 2010 (photo by M. Perušić)

na, kupola s donjim vijencima iznad tambura), aplicirani su preostali izvorni cinčani ukrasi, maskeroni, girlande i sl. koji su zbog usklađivanja s bakrom prebojeni u crveno (sl. 19, 23a). Popravljana je izvorna stolarija u gornjoj etaži, a zamijenjeni su samo neki uski prozori i stijene s ulaznim vratima. Dovratnici s kutijama roloa u maloj dvorani su demontirani. U donjoj etaži, otvori pročelja s polukružnim nadsvjetlima, ispred stolarije vrata i stijena $\mathrm{u}$ razini terena, imali su izvorne metalne roloe-eslingere za zaštitu, koji su demontirani. Oko polovice stavaka je popravljano, a polovica s vratima je zamijenjena. Desetak otvora zatvoreno je oblogama. Kamenarski radovi obuhvatili su čišćenje vijenaca, prelaganje i obradu vanjskog stubišta i bočnih ograda, a staklarski zamjenu stakala kupole s pjeskarenim žičanim staklom.

Kvaliteta izvedbe mogla se vidjeti tek kad su postavljene skele za recentnu obnovu..$^{\circ}$ Nedostataka je bilo i u kvaliteti radova. Produžna cementna žbuka, a posebno boja, odvajala se od podloge, sve profilacije nisu izvedene šablonama, a ukrasna plastika u žbuci uglavnom je samo višeslojno premazivana. O restauratorskim radovima nema podataka. Posebno je loše bilo postavljanje cinčanih ukrasa na novu bakrenu limariju donjeg vijenca kupole sa žlijebom, izvedenu bez profilacija. Samo pola girlanda je ovlaš razmješteno. Od prvotna dvadeset četiri maskerona, postavljeno je petnaest, koji su nađeni nagnuti i neučvršćeni u ležišta; dva su pala i razbila stakleni pokrov. Raščlanjeno pročelje s mnogo istaka nije dobilo zaštitu od ptica, osim na timpanima gdje su postavljene željezne mreže koje hrđaju.

Godine 1994. obnovljen je plan da se u donjem prizemlju ponovno otvori restoran. Prema projektu arhitekta Zvonimira Krznarića, preuređena je cijela etaža. Zbog predimenzioniranog programa za ugostiteljstvo, sa sjeverne strane ispod terena dograđene su pomoćne prostorije kuhinje i spremišta, veličine 20 x $10 \mathrm{~m}$ i veliki šahtovi za instalacije. Administrativni i servisni prostori paviljona s ravnateljevom sobom su dislocirani; postali su dostupni iz dužeg izlomljenog hodnika u istočnom krilu. Restoran nije bio povezan s gornjom etažom, već je ulaz bio samo iz parka s juga. Radio je do 2009 . godine.

Sadašnje uređenje vestibula - ulaza u izložbeni prostor, info-punkta s blagajnom i bočnih kancelarija izvedeno je 1997. prema projektu arhitekta Marija Beusana. ${ }^{51}$

\section{Konzervacija i restauracija 2000. - 2013.}

Temeljitoj obnovi pročelja reprezentativne zgrade Umjetničkog paviljona pristupilo se ponovno 2001. godine. Gradski zavod za zaštitu spomenika kulture i prirode, kao nadležna služba zaštite, bio je pozvan u vezi s pripremama za održavanje izložbe Andyja Warhola. ${ }^{52}$ Traženi su posebni klimatizacijski uvjeti i mogućnost potpunog zasjenjenja izložbenog prostora, što do tada nije bilo moguće. Prema smjernicama i konzervatorskom nadzoru Gradskog zavoda za zaštitu spomenika kulture i prirode, koji je vodio Mladen Perušić, u kratkom vremenu is ograničenim sredstvima izvedena je klimatizacija prema projektu i u izvedbi Klime Zagreb (Marijan Kelemen, str. teh.) te nadzoru Termotehničkog inženjeringa (Stevo Ivanišević, dipl. ing. str.). U niše parapeta dvorana ugrađeni su klimatizacijski uređaji, a u šahtove sa sjeverozapadne strane klimatizacijske komore. UV folije položene su iznad stakala podgleda stropa. Radovi su bili dovršeni do rujna 2001., a dislokacija komora 2002. godine.

Warholova izložba ukazala je na potrebu osiguranja boljih prostornih uvjeta za postavljanje raznovrsnih izložbi. Stoga je 2004. slijedila izrada projekata rekonstrukcije rasvjete dvorana. Prvi projekt izradili su Vladimir Brečak, dipl. ing. el., i arhitekti Rikard Slavica i Ivančica Morsan. ${ }^{53}$ Osim nove rasvjete trebalo je sanirati i staklene krovove bočnih izložbenih dvorana jer su propuštali oborine. Prema smjernicama GZZSKIP-e, arhitekt Željko Kovačić 2005. izradio je arhitektonski projekt zamjene stakala pokrova istočne i zapadne dvorane i koncept rasvjete 


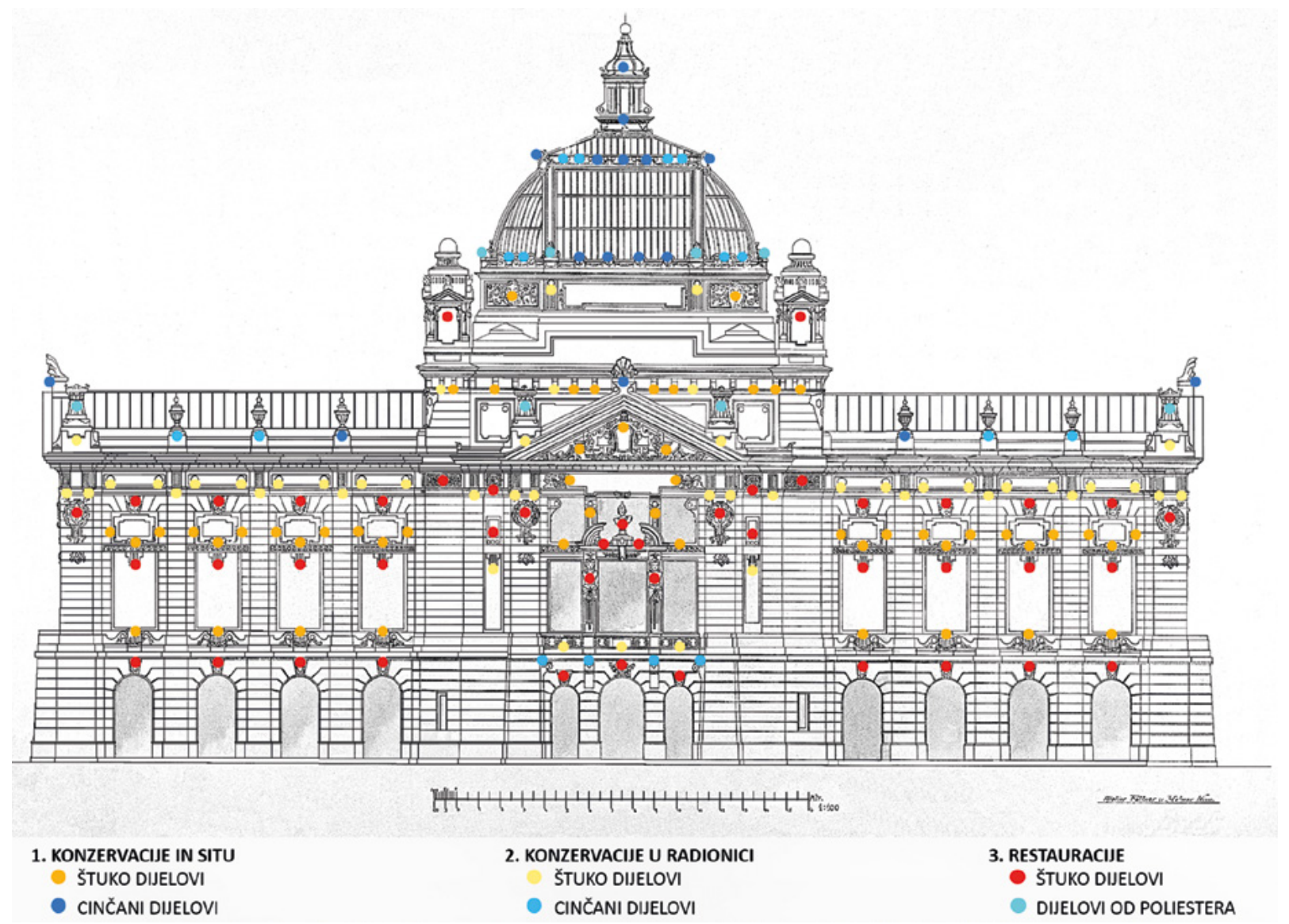

24. Nacrt južnog pročelja s označenim zahvatima (dokumentacija M. Perušić)

South façade - details of intervention (made by M. Perušić)

interijera izložbenog prostora. Projekte elektroinstalacije i konstrukcije nosača izradili su inženjeri Erol Čić i Branislav Škoro. ${ }^{54}$ Radove je 2006 . vodila ekipa arhitekata: predstavnica investitora iz Ureda za graditeljstvo, Sektora za građenje objekata društvenih djelatnosti, Maja Čar Paić, konzervatorski nadzor Gradskoga zavoda za zaštitu spomenika kulture i prirode Mladen Perušić i Maja Gorianc Čumbrek, nadzor Bi-biro Ivanka Divjak, a izvođač radova bio je Ta-grad. Sustav sofisticirane rasvjete kojom su omogućene suvremene postave izložbi demonstriran je 13 . listopada 2006. Višebojno rasvijetljena kupola i ostakljeni krovovi bili su likovni doprinos uređenom ambijentu.

Nakon završetka radova odlučeno je da se pripremi sljedeća etapa koja je podrazumijevala obnovu kupole i razvedenih pročelja zgrade. Grad Zagreb, kao vlasnik Umjetničkog paviljona i investitor, uvrstio je te radove u program spomeničke rente, čime su osigurana financijska sredstva. Sektor za građenje sastavio je projektni zadatak za izradu glavnog i izvedbenog projekta, prema konzervatorskim smjernicama GZZSKIP-a koje su izradili Mladen Perušić i Maja Gorianc Čumbrek na način konzervacije i restauracije prvotno izvedenog stanja jer je ustanovljeno da postoji dovoljno argumenata za takvu izvedbu. Za paviljon na istaknutoj lokaciji Zelene potkove projektirana je i ostvarena reprezentativna arhitektu- ra koja je najvećim dijelom očuvana. Naime, za realizaciju i koncepciju najvažnije je bilo skulptoralnu plastiku konzervirati, samo manji dio elemenata trebalo je izvesti prema sačuvanim i u konačnici dodati neke elemente uklonjene $1938 . .^{55}$

Za izradu projekta odabran je u prosincu 2006. Capital-ing. Na izvedbeni projekt, nakon dorade, 27. travnja 2007., izdano je rješenje Zavoda. ${ }^{56}$ Investitor je za izvođenje radova i nadzor odabrao ekipu kao 2006.: za predstavnice investitora arhitektice Maju Čar Paić (2006. - 2009.) i Gordanu Butković (2009. - 2013.), za nadzor Bi-biro, Ivanku Divjak. Konzervatorski nadzor GZZSKIPa nad svim radovima nastavili su voditi Mladen Perušić (2001. - 2010.) i Maja Gorianc Čumbrek (2006. - 2013.). Rukovoditelj gradilišta izvođača Ta-grada bio je Antun Trojnar, ing. građ. Početak radova određen je danom 6 . listopada 2007.

Stvarno stanje vanjštine građevine moglo se ustanoviti tek nakon postave skela. Nadležni konzervatori su sa šefom gradilišta 2. studenoga 2007. pažljivo pregledali sve dijelove pročelja, kupolu, ravne plohe zidova s istacima i dilatacijama, profilacije, arhitektonsku plastiku i sve uskrasne elemente. Nakon toga su 7. prosinca 2007. s restauratorima, akad. kiparima Ivanom Briskim i Aldom Krizmanom, određena i mjesta izrade restauratorskih 
sondi. ${ }^{57}$ Tom je prilikom utvrđeno nekoliko zanimljivih podataka o ikonografskom sadržaju ukrasnog repertoara pročelja. Dosad se, primjerice, držalo da su u timpanonu sjevernog i južnog pročelja reljefi alegorija slikarstva i kiparstva. Međutim, lijevi lik predstavlja graditelja, a ne slikara, jer se na crtaćoj ploči koju drži nalazi tlocrt crkve, a on žmiri na jedno oko procjenjujući proporcije. Uz lik su i drugi atributi koji sugeriraju upravo arhitekturu, jonski kapitel i kanelirano tijelo stupa (sl. 20, 21).

Prikupivši nadalje arhivsku građu i literaturu o povijesti građevine te novosnimljenu fotodokumentaciju, izrađene su konzervatorske smjernice i sastavljen troškovnik radova na pročelju. Glavni cilj bio je restitucija izvornoga stanja, jer je ustanovljeno da postoji dovoljno elemenata za takvu izvedbu. Zatečeno je, naime, purificirano stanje zbog uklanjanja dijela ukrasa 1938. - 1940. godine. Usporedbom projekata iz 1897., niza fotografija prije 1938. i zatečenog stanja gdje je još bilo izvornih dijelova, izrađen je pregled potrebnih zahvata i sheme za izvedbu građevinskih i restauratorskih radova. Troškovnik je sadržavao više desetaka stavaka i više od tisuću sto elemenata arhitektonske plastike, koji su specificirani u tri skupine (sl. 24). U prvoj su veliki elementi, izvorni kiparski odljevci, koji se konzerviraju in situ, kao duboki reljefi u timpanima, niše s poprsjima na istočnom i zapadnom pročelju, kružne i lučne profilacije i ukrasi vijenaca, girlande na tamburu i razdjelnom vijencu prizemlja konzole krovnog vijenca, postolja skulptura i izvorne veće cinčane profilacije, lukarne, uglovni akroteriji, lanterna. U drugoj su skupini oni elementi koji se mogu demontirati i konzervirati $u$ radionici radi lakšeg rada ili trebaju poslužiti kao uzorci za restauratorsku izradu novih na mjestima gdje nedostaju. To se uglavnom odnosi na ukrasnu plastiku od cinčanog lima na vijencu kupole, na maskerone, vaze, girlande i nekoliko detalja arhitektonske plastike za odljevke triglifa na frizu i konzola na krovnom vijencu (sl. 23b). U trećoj skupini je izrada novih elemenata koje treba restaurirati jer ne postoje, kao žare, modiljoni sa školjkom na dnu bridova kupole, završeci tornjića dimnjaka i ventilacija, kazete na frizu krovnog vijenca, volute i triglifi u kazetama između pilastara, maskeroni u zaglavnim kamenima lukova otvora, girlande - vijenci s grbovima na uglovnim pilastrima, herme i poprsje Atene..$^{8}$

Radovi su se obavljali u nekoliko etapa, uglavnom kontinuirano, prema pritjecanju sredstava iz spomeničke rente. Sklopljena su četiri ugovora, dva za građevinsko-obrtničke radove pročelja i kupole (6. 8. 2007. i 15. 1. 2009.) te za kiparsko-restauratorske radove (15. 1. 2009.) i potom za rekonstrukciju dimnjaka kotlovnice, sanaciju balkona, vlage i sanitarija $u$ donjoj etaži s vanjskom temeljnom kanalizacijom (13. 3. 2012.). Koordinacije gradilišta održavale su se $u$ vrijeme radova jedanput tjedno, a prisutni su bili, osim navedenih predstavnika i restauratora, i

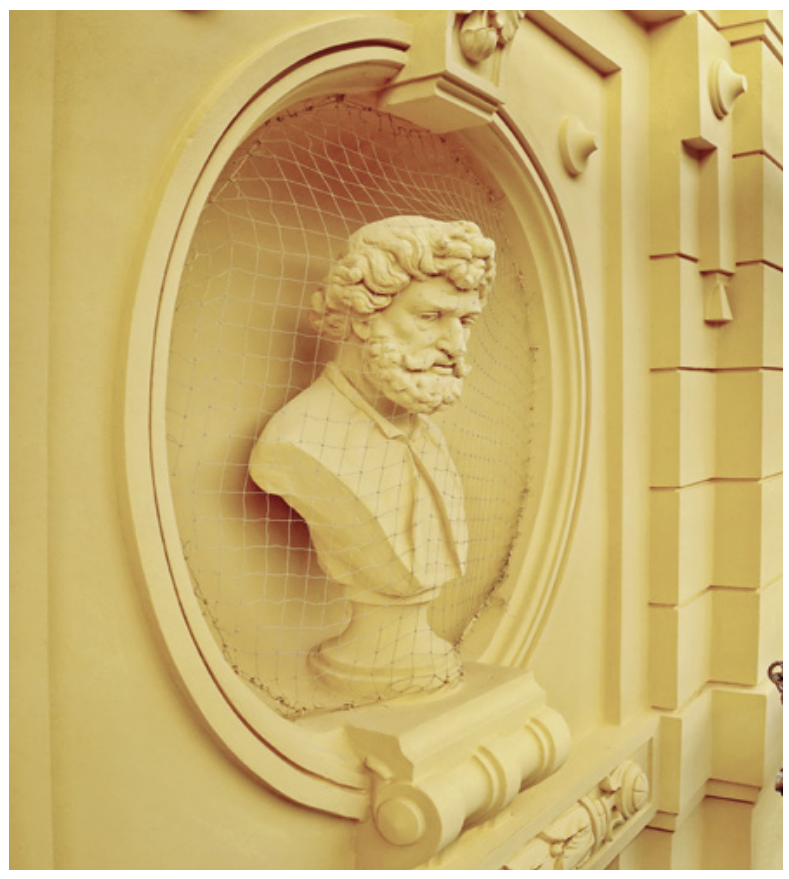

25. Niša s poprsjem Andrije Medulića, 2010. (snimio M. Perušić) Niche with the bust of Andrija Medulić, 2010 (photo by M. Perušić)

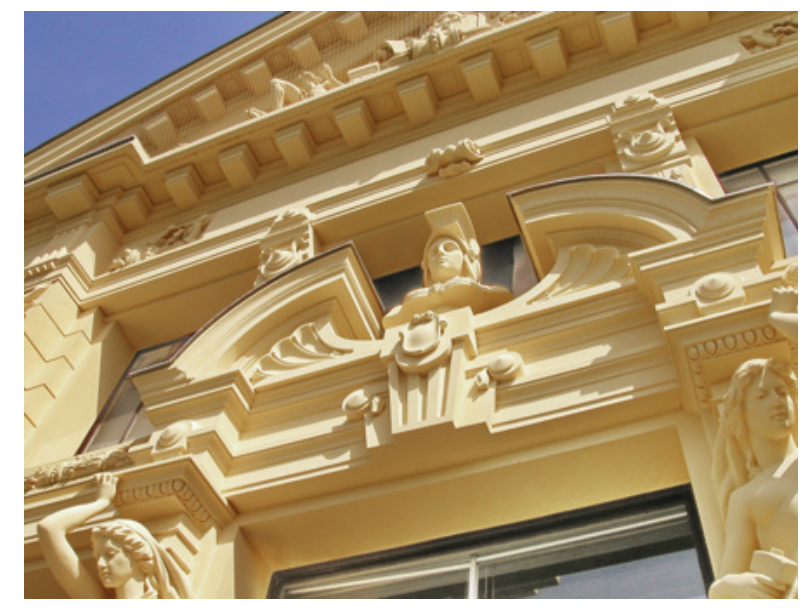

26. Detalj portala ulaza, 2013. (snimila M. Gorianc Čumbrek) Detail of the entrance portal, 2013 (photo by M. Gorianc Čumbrek)

predstavnici korisnika, ravnatelj prof. Radovan Vuković, prof. Stanko Špoljarić ili Damir Martinec. ${ }^{59}$

Više specijaliziranih ekipa kooperanata $u$ teškim je uvjetima saniralo posebno oštećene dijelove kupole. Najsloženiji građevinski zahvat bilo je skidanje limenih ploha na daščanoj oplati s gredama, na kraćim stranama osmerokutne kupole (koje su prenesene iz Budimpešte) i izvedba ostakljenja, kako je bilo predviđeno u projektu Fellnera i Helmera. U tu su svrhu izrađene posebne skele $u$ unutrašnjosti kupole, razuprte bočno u zidove da ne smetaju u središnjem izložbenom prostoru. Sve čelične konstrukcije obradila je i izradila bravarska radionica Šturman. Zamijenjeno je žičano staklo kupole i ugrađeno na način prvotne izvedbe s preklopima poput crijepa i s 


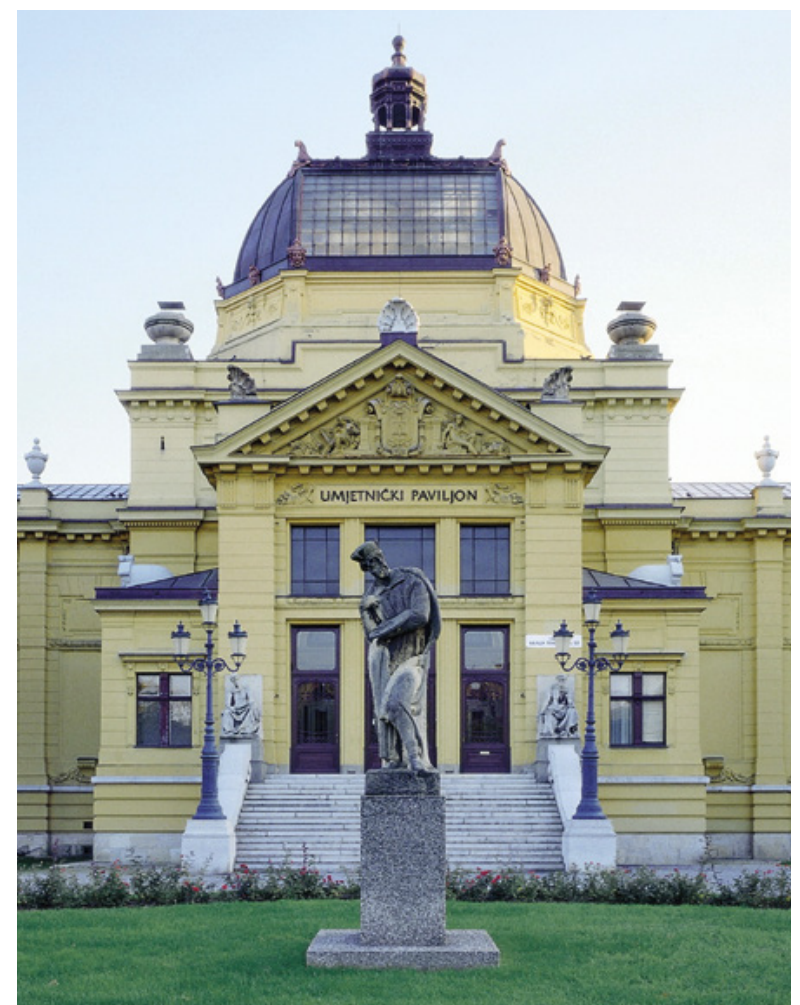

27. Srednji dio sjevernog pročelja, 1998. (snimio D. Fabijanić) Central portion of the north front, 1998 (photo by D. Fabijanić)

elastičnim brtvljenjem, kao i na krovovima dvorana. Staklarske radove izvela je tvrtka Staklo Piletić. Na nekoliko mjesta skinuta je oštećena limarija i postavljena cinčana, kakva je bila izvorna. Sustav odvodnje oborinskih voda s kupole trebalo je također preraditi jer su vertikale bile izvedene s više prijelaza s fasada $u$ unutrašnjost. Neki spojevi nisu ni brtvili. Nova gromobranska instalacija povezivanja metalnih elemenata sa šipkama uređena je tako da ima što manje istjecanja i uz oluke. Zidarski radovi bili su većeg opsega, budući da je u dva navrata, 1938. i 1986., veći dio vapnene žbuke pročelja zamjenjivan cementnom, koja se odvajala od podloge. Posebno su na više mjesta bile loše izvedene profilacije razdjelnih i krovnih vijenaca, konzola i obruba kazeta u tamburima. Na plohama zidnih polja između pilastara uopće nije bio u žbuci izveden raster reški, imitacije klesanaca kamenog opločenja. Stoga je trebalo zamijeniti takvu žbuku novom. ${ }^{60}$ Specijalizirani zidari izradili su četrdesetak šablona profilacija prema uputama i ovjeri konzervatorskog nadzora. Restauratorskim sondama na žbuci na svim je dijelovima nađen jednobojni premaz. Ton boje određen je $u$ listopadu 2009. nakon izrade dvadeset uzoraka. Pročelja su obojena u tehnologiji silikonskih boja s primjerenim podlogama. ${ }^{61}$ Za svu limariju, preostalu bakrenu i novu od cinčanog lima-cinkotita (slitine 99\% cinka i 1\% titana) odabran je ton prema prirodnoj boji cinčanoga lima koji je nađen na sačuvanim ukrasnim elementima na kupoli. Prema tonovima na restauratorskom sondama bojene su,

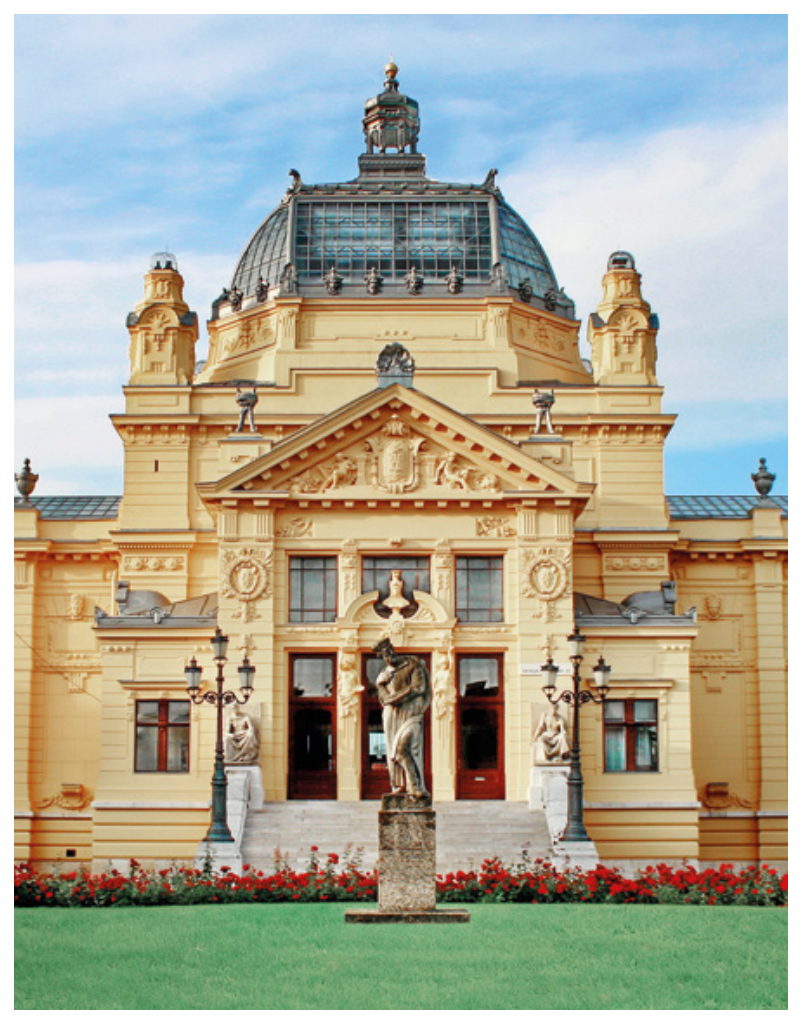

28. Srednji dio sjevernog pročelja, 2013. (snimio D. Fabijanić) Central portion of the north front, 2013 (photo by D. Fabijanić)

nakon obrtničke sanacije, stolarija i bravarija. Na zgradi je ugrađeno nekoliko vrsta kamena. Prilazno stubište $s$ ogradnim zidovima i razdjelni vijenac u razini poda ulaza, ogradi i podu balkona su od kraškog vapnenca, varijeteta fiorito iz okolice Trsta, naziva Repen-Kopriva, koji je čvrst i ne upija vodu. Kameni sokl gornje i donje etaže je bizek. Skulpture Rudolfa Valdeca, alegorije slikarstva i kiparstva, izrađene su od vinicita. Ugrađeni kamen zidnih obloga nije bio znatnije oštećen pa je obrađivan samo površinski, čišćenjem, mjestimičnim ispunjavanjem reški kamenim mortom i zaštićen premazima. Kamene masivne stube ulaznog stubišta su demontirane zbog izvedbe podloga i nepropusnog stropa nad sanitarijama. Nakon obrade i nekoliko zamjena novim iste kvalitete, postavljene su prema nacrtu konzervatora. Kamenarske radove izvodila je u srpnju 2008. Klesarija Jerbić.

Posebna pozornost posvećena je radovima konzervacije i restauracije koji su izvedeni prema, navedenom, zasebnom troškovniku, uz konzervatorski nadzor predstavnika GZZSKIP-a. Izvedba je povjerena kooperantima Ta-grada, akademskim kiparima Ivanu i Branku Briskom, Aldu Krizmanu i Goranu Mišiću koji su predvodili dvadesetak restauratora. Na početku radova, prilikom izrade restauratorskih sondi, na više mjesta na zidovima su pronađeni tragovi formi i geometrije elemenata uklonjenih 1938., što je bila potvrda da je ukrasna plastika, prikazana u detaljnim nacrtima, bila u tim mjerama i izvedena. Sva sačuvana izvorna plastika konzervirana je in situ: arhitektonska, 


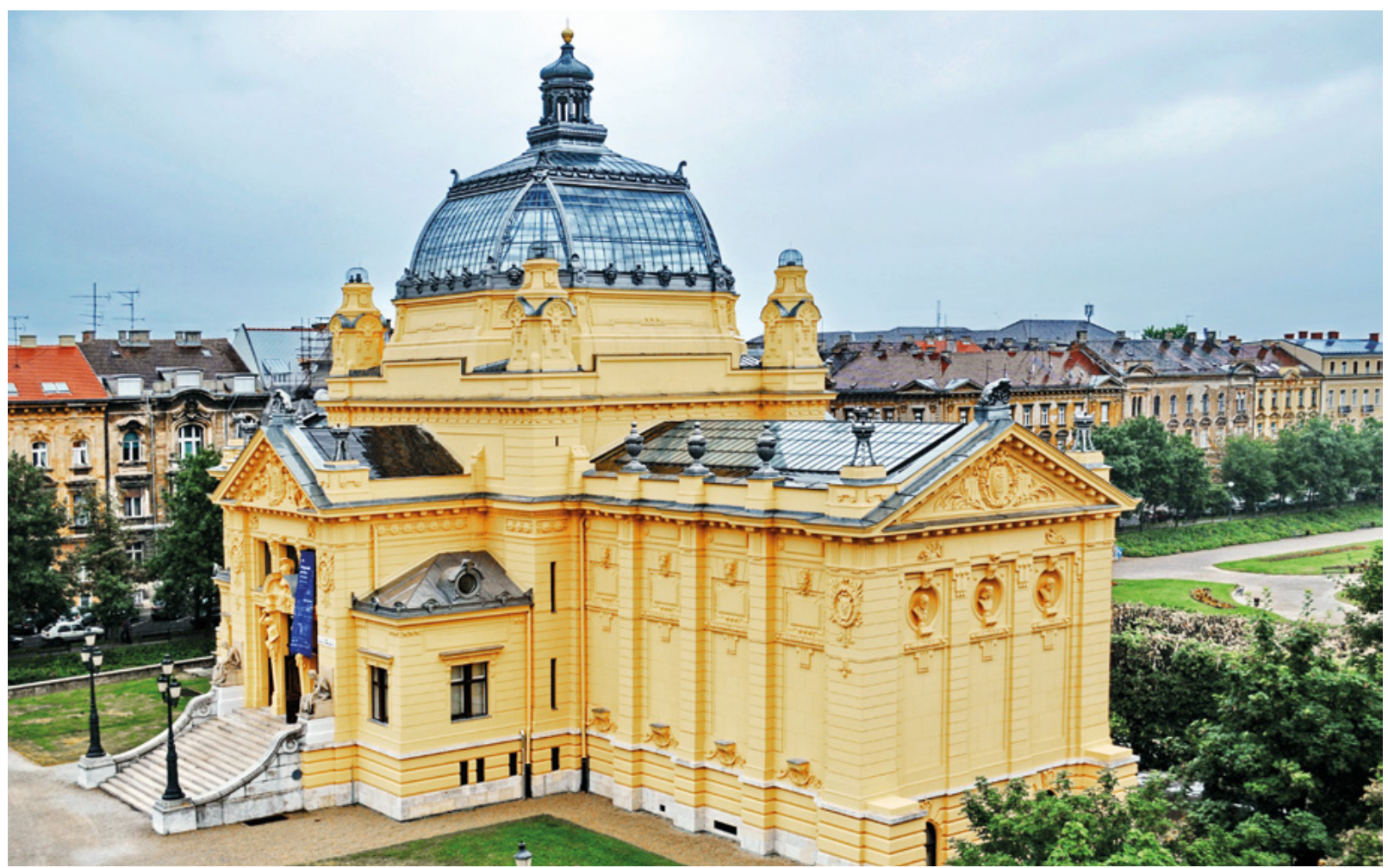

29. Umjetnički paviljon nakon obnove, 2013. (snimio M. Perušić)

Art Pavilion after renovation, 2013 (photo by M. Perušić)

lučne i kružne profilacije u žbuci, niše, konzole krovnih vijenaca, modiljoni, razne volute i drugo, kao i skulptoralna, ornamentika s floralnim motivima i figuralna, reljefi u timpanima i nišama, biste Medulića (sl. 25), Klovića i Carpaccia, na istočnom pročelju i Michelangela, Rafaela i Tiziana na zapadnom. Ovisno o dubini oštećenja, lijevana plastika sanirana je specijalnim mineralnim žbukama za renoviranje i saniranje. ${ }^{62}$ Radovi konzervacije na skeli zbog opsega i vremenskih uvjeta bili su najzahtjevniji dio posla. Radila je cijela ekipa restauratora, predvođena voditeljima. Na kupoli su veći izvorni elementi od cinčanog lima, kao lanterna, akroteriji, girlande na vijencu, lukarne, također konzervirani in situ, a obrađivao ih je Branko Briski. Dijelovi ukrasne limarije bili su oštećeni i zbog toga jer su od tankog lima; posebno vaze nad krovnim vijencem bočnih dvorana. Maskerone, girlande, stošce, vijence s grbovima i volute, koji su zbog obrade ležišta skinuti, trebalo je nakon čišćenja, mjestimične popune rupa i pripreme za ličenje ponovno pričvrstiti u obrađena ležišta. Nedostajući dijelovi su, nakon izrade kalupa prema tim elementima, lijevani u poliesteru i obrađeni epoksidnim prajmerom za ličenje. Kiparski elementi, koji su s pročelja skinuti 1939., restaurirani su prema uvećanim detaljnim nacrtima i fotografijama izvornog stanja. Restauratori su radili timski i preklapali se u kreaciji zahtjevnijih elemenata; surađivali su u dogovorima s konzervatorskim nadzorom. U atelijerima voditelja izrađivani su uzorci u glini, kalupi i odljevci od smjese sitnog kame- nog agregata 0-2 mm i bijelog cementa te su ugrađivani s nehrđajućim sidrima. Dijelom je to bila arhitektonska plastika od lijevane mase i skulptoralna s floralnim motivima, grbovi Trojedne Kraljevine, akroteriji, žare, obloge dimnjaka uz kupolu koju su vodili Aldo Krizman i Ivan Briski, a lijevano je pretežito u ateljeu Gorana Mišića. Velik trud uložen je u izradu figurativne plastike, glave na tjemenim pločama polja i nadvoja otvora, herme i poprsje Atene. Taj dio skulptura u dubokom reljefu uglavnom je radio Ivan Briski (sl. 26).

Nakon demontaže skela, koje su s kupole skinute $\mathrm{u}$ prosincu 2009., a s pročelja u kolovozu 2011., omogućen je pristup prizemlju i podnožju zgrade i izvedbi radova treće etape, koji su obuhvaćali sanaciju južnog balkona, vlage na zidovima restorana, rekonstrukciju kotlovnice s novim dimnjakom, sanitarnog čvora sa zamjenom vanjskih instalacija. Predstavnice gradskih službi bile su arhitektice Gordana Butković i Maja Gorianc Čumbrek. Projekt i nadzor građevinskog dijela vodila je arhitektica Ivanka Divjak, a strojarskih instalacija Slobodan Somer, dipl. ing. str. Radovi su počeli 7. svibnja 2012., a konačna primopredaja cjelokupnog zahvata održana je 14. svibnja 2013. ${ }^{63}$ Stanje južnog balkona otkriveno je nakon skidanja obloga konzola koje su izvedene 1994. nad ulazom u restoran. S donje strane, kamene su ploče imale pukotine jer su nosači-čelične traverze bile nagnute iz ležaja i trebalo ih je zamijeniti. Prema propisima, rad plinske kotlovnice uvjetovan je izvedbom novog dimnjaka. Budući da je 
ulična kanalizacija na višoj razini od donje etaže paviljona, izvedeno je prepumpno okno s automatskim crpkama. Nakon skidanja skela balkona i dimnjaka, na obje su strane portala postavljene herme i poprsje Atene, zaštitnice umjetnosti i zanatstva (sl. 26). U svibnju 2013. završeni su svi ugovoreni radovi, ${ }^{64}$ a voditelji projekta Maja Gorianc Čumbrek i Mladen Perušić iste su godine nagrađeni Godišnjom nagradom Ministarstva kulture „Vicko Andrić“, uz obrazloženje: „Za izvrsnost izvedbenog elaborata te za vođenje zahtjevne obnove pročelja, kupole i krova Umjetničkoga paviljona u Zagrebu od 2006. do 2013. godine.“

\section{Zaključak}

Umjetnički paviljon u Zagrebu jedinstveno je arhitektonsko naslijeđe, sačuvano najvećim dijelom u sloju iz vremena gradnje 1898 ., cjelina u eksterijeru i interijeru i kontinuiranoj javnoj funkciji izložbene djelatnosti. U recentnoj sveobuhvatnoj konzervaciji i restauraciji vanjštine zgrade primijenjen je model prezentacije posljednjeg živog sloja koji je ujedno i prvotni, na kojem su primijenjene intervencije konzervacije izvorne supstancije in situ. Zahvati na pročeljima 1938. i 1987. nisu donijeli slojevitost niti stvorili nove vrijednosti jer su u biti obuhvaćali pojačano održavanje s dva betonska dodatka na krovu. Reprezentativna zgrada na istaknutoj lokaciji zagrebačke Zelene potkove i magistralnom smjeru kretanja projektirana je i izvedena s bogatom historicističkom dekoracijom ikonografskog programa koja je konstituitivni dio oblikovanja pročelja. Zbog cjelovitosti prezentacije izvornog stanja, nekoliko je elemenata skulptoralnih ukrasa, skinutih 1938., restaurirano. Potpuno ostakljenje kupole jedini je zahvat rekonstrukcije uz osuvremenjenje instalacija, što je bilo nužno za poboljšanje uvjeta osnovne djelatnosti (sl. 27-29).

\section{Bilješke}

1 Zavod za zaštitu spomenika kulture grada Zagreba prilikom izrade prvog popisa spomenika odredio je 1962. da se zgrada Umjetničkog paviljona upiše u Registar nepokretnih spomenika kulture. Svojstvo je potvrđeno i u najnovijem Registru kulturnih dobara Ministarstva kulture $\mathrm{RH}$, pod brojem Z-222.

2 DINKo ŠokČEvıĆ, $\underline{U}$ ogledalu, nejasno, Mađarski milenij u očima hrvatske javnosti, Kolo XII, 3, 2002., 45-57.

3 Izložba je održana na prostoru središnjeg gradskog parka u Budimpešti, a tri paviljona i kušaonica Kraljevine Hrvatske i Slavonije bili su smješteni na povoljnom mjestu, između dva glavna ulaza. Na situacijskom nacrtu izložbe, na sl. 1, paviljoni su tamnije označeni, a Paviljonu umjetnosti je dodana strelica. Karta uz stražnje korice u: Kraljevine Hrvatska i Slavonija na Tisućgodišnjoj zemaljskoj izložbi Kraljevine Ugarske u Budimpešti 1896., Zagreb 1896. 4 Okolnosti o tome su poznate i iscrpno dokumentirane i prikazane u radovima Snješke Knežević, Olge Maruševski i Lee Ukrainčik. SNJEŠKA KNEŽEVIĆ, Zagrebačka Zelena potkova, Zagreb, 1996., 148-159., 359-360.; OLGA MARUŠEVSKI, Gradnja umjetničkog paviljona, Okrunjeni trg, Hrvatski salon 1898., Zagreb, 1999., 255-271.; OLGA MARUŠEVSKI, Društvo umjetnosti 1868. - 1879. - 1941., Zagreb, 2004., 150156 i dr., LEA UKRAINČIK, Umjetnički paviljon 1898. - 1998., Zagreb, 2000., 7-29.

5 DURm, JOSEF, Handbuch der Architektur, 4. Theil, 4. HalbBand, 4. Heft, Ausstellungbauten, Darmstadt 1893., 472-534. 6 Državni arhiv u Zagrebu, Gradsko poglavarstvo Zagreb, Građevni odsjek, sign. 222. U tri kutije dokumentacije nalaze se i arhitektonski nacrti koji nisu složeni po skupinama kronologijom izrade. Razlog je možda i u tome što pojedini nacrti nemaju nikakav tekst, naziv, potpis i datum ili postoje samo neki podaci. Stoga je nakon pregleda i analize građevinskih elemenata većina kopirana i sistematizirana u svrhu izrade konzervatorskih smjernica Gradskog zavoda za zaštitu spomenika kulture i prirode u Zagrebu (M. Perušić, M. Gorianc Čumbrek). U prvoj skupini su projekti arhitekata Florisa Korba i Kálmána Giergla. Natječajni rad, tlocrt, poprečni presjek i glavno, sjeverno pročelje su u mjerilu 1:100 s potpisima autora. Tlocrt za izvedbu je u istom mjerilu, nema nikakvih natpisa, samo su olovkom prekriženi neki projektirani dijelovi, dopunjene kote i obodno upisani izračuni pa je evidentno da je služio za izvođenje.

7 Oko središnjega kvadrata stranice 13,2 m, baze kupole, adirana su dva bočna izdužena krila dvorana, svijetlih mjera $17 \times 10 \mathrm{~m}$, s južne strane pravokutni ulazni rizalit veličine $16,8 \times 5,5 \mathrm{~m}$, s vestibulom $9,7 \times 5,5 \mathrm{~m}$, s četiri stupa, sobom portira, garderobom i sanitarijama, po $3,3 \times$ $5,5 \mathrm{~m}$, a sa sjeverne nasuprotne strane četvrta manja dvorana veličine $13,5 \times 5,5 \mathrm{~m}$. Dakle, prostor paviljona je vrlo racionalno i funkcionalno organiziran. Vanjske mjere gabarita Paviljona, 53,3 x 26,1 m, ucrtane su u situacijskom rješenju s ostala tri paviljona; situacijsko rješenje nalazi se u Nadbiskupskom arhivu, zbirka nacrta Dijecezanskog muzeja, sign. VII-2.

8 Obodni zidovi su debljine jedne opeke, $30 \mathrm{~cm}$, s trostranim proširenjima, ukrutama, oko čeličnih nosača, pod kupolom debljine dviju opeka, $60 \mathrm{~cm}$, a pregradni od polovice opeke, $15 \mathrm{~cm}$. Stoga su promijenjene i veličine prostorija, a bočne dvorane su povećane na 17,8 x 10 m.

9 Dokumentacija citirana u bilješci 6 . Zanimljivo je da su navedeni elementi većim dijelom primijenjeni i u projektu za Zagreb. 
10 Prema fotografijama paviljona, vidljivo je da nisu izvedeni neki planirani elementi dekoracije: kipovi muza alegorije umjetnosti uz osam bridova kupole, niti oslikana draperija u gornjem dijelu polja zidova dvorana. Paviljone kraljevina Hrvatske i Slavonije fotografirao je Gjuro Klösss. Državni arhiv u Zagrebu, Fond 135, sign. 22099.

11 Kraljevine...,1896. (bilj. 3), u knjizi-katalogu izlošci u Paviljonu Historije i umjetnosti, Poviestni spomenici popisani su na str. 205-227:, a drugom dijelu Umjetnost i vještine na str. 1-11.

12 SNJEŠKA KNEŽEVIĆ, 1996., (bilj. 4), 359.

13 Državni arhiv u Zagrebu, Gradsko poglavarstvo Zagreb, Građevni odsjek, sign. 222. Na tri plave ozalidne kopije, tlocrta, presjeka i glavnog pročelja u mjerilu 1:100, u donjem desnom kutu nacrta su pečati tvrtke Danubius s potpisom Baumgarten, a lijevo od pečata parafi projektanata Florisa Korba i Kálmána Giergla. Na nacrtu čelične konstrukcije je tlocrt u mjerilu 1:100 i četiri karakteristična presjeka samo pečat Danubiusa. Četvrti nacrt je situacija, a peti nacrt iz serije Danubiusa, izrađen za paviljon u Zagrebu; detalj okruglog željeznog stubišta za mezanin ima samo pečat tvrtke s datumom 23. 4. 1897.

14 Pri izradi žbuke na pročeljima, na nekim su mjestima pronađeni vertikalni stupovi presjeka $45 \mathrm{~cm}$, sastavljeni od po četiri kutnika povezana kosim prečkama, koji su pomaknuti u odnosu na mjesta ucrtana u projektu. $\mathrm{Na}$ pitanje je li već prilikom gradnje paviljona u Budimpešti izveden drugačiji sustav od prikazanog projektom i takav premješten u Zagreb ili je za Umjetnički paviljon izrađen novi, za sada nije moguće decidirano odgovoriti.

15 SNJEŠKA KNEŽEVIĆ, 1996., (bilj. 4), 153.

16 Vidi bilješke 6 i 13. Drugu skupinu nacrta čine projekti za Zagreb. Na svim listovima u donjem desnom kutu stoji Atelier Fellner u. Helmer Wien,. Tlocrt, presjek i oba duža pročelja u mjerilu 1:100 imaju parafe Fellner u. Helmer, Wien, aug. 97. i parafe izvođača Hönisber Deutcsh. Na drugom tlocrtu prizemlja i tlocrtu mezanina u mjerilu 1:100, vestibula 1:20, nacrtu stolarskih shema 1:25, nema potpisa ni datuma izrade, a na dva detalja tlocrta ukrasnog ostakljenja stropa nema nikakvog opisa.

17 Vidi bilj. 16. Na četiri nacrta detalja pročelja i stolarije u mjerilu 1:25 nema potpisa ni datuma izrade, već samo natpis Atelier Fellner u. Helmer Wien i na jednom paraf nadzornika, Bergman.

18 Vidi bilj. 16. Arhitekti Fellner i Helmer su 27. 8. 1897. parafirali taj tlocrt prizemlja u mjerilu 1:100. Rješenje se oslanja na prvi projekt Korba i Griegla.

19 Vidi bilj. 16. Drugi tlocrt prizemlja, u mjerilu 1:100, prema kojem se izvodilo, ima samo natpis Atelier Fellner u. Helmer Wien.

20 SNJEŠKA KNEŽEVIĆ, 1996., (bilj. 4), 153.

21 Vidi bilj. 16. Tlocrt dijela lijeve strane zgrade vanjskog i unutarnjeg stubišta, vestibula, središnje i bočne dvorane, u mjerilu 1:25, prema kojem se izvodilo, ima samo natpis
Atelier Fellner u. Helmer Wien. Za mezanin nije produženo glavno stubište, nego je prema detaljnom nacrtu izvedeno kružno koje je projektirano za prilaz krovištu u jugoistočnom tornju.

22 Vidi bilj. 15. Prezentirani nacrti u mjerilu 1:25 imaju oznake, list 17 od 26. VIII. 97., a drugi list 26, od 3. IX. 97., imaju natpis Atelier Fellner u. Helmer Wien, a prvi i paraf Bergman i datum 12. II. 98. Sačuvana su samo još dva detaljna nacrta, pročelja i stolarskih shema list $4 . .$. od 10. 12. 97., što ukazuje na to da je, budući da su numerirani i označeni datumom, vjerojatno bilo više od 40 listova.

23 Zagreb od godine 1892. do godine 1902., 1902., 19. U tablici razdiobe investicija od godine 1888. do 1902. za Umjetnički paviljon naveden je iznos od 260.875 kruna i 12 filira. Isti trošak za gradnju donosi i Gjuro Szabo u knjizi Stari Zagreb, str. 215. lako se u suvremenom tisku i literaturi navode iznosi od 132.600 (Narodne novine) i 150.000 kruna (Chvala), prvi iznos je službeni podatak iz navedene spomenice.

24 Narodne novine 15. 12. 1898. Domaće viesti, Svetčano otvorenje umjetničkog paviljona i umjetničke izložbe u Zagrebu, 15. prosinca.

25 JOSIP CHVALA, Umjetnički paviljon u Zagrebu, Viesti družtva inžinira i arhitekata u Hrvatskoj i Slavoniji, br. 5, 15. srpnja 1900.

26 Obzor, 16. 8. 1902. Zanimljiva je pojedinost da je u paviljonu 1900. bilo sjedište kazališta Urania koje je održavalo predstave sa slikama. U prosincu su Oton Kučera i Izidor Kršnjavi predavali o astronomiji i svjetskoj izložbi u Parizu, a u biblioteci Uranie ta su predavanja objavljena. Ulaznice su se prodavale u knjižari Lava Hartnmana.

27 Obzor, 9. svibnja 1898.

28 antun Gustav matoš, Misli i pogledi, Zagreb, 1988., Umjetnički paviljon, 402., izvorno 1908. XI, 39-40.

29 GJURO SZABO, Stari Zagreb, Zagreb, 1941., 215.-16.

30 IVO ŠREPEL, Pedeset godina hrv. umj. likovnog stvaranja iz „Obzorove“ perspektive (1885.1935) Obzor 1860. -1935., 262-3.

31 Ploče žičanog stakla su malog formata zbog zakrivljenosti ploha, izložene zagrijavanju i time širenju i stezanju. Plohe s mnogo spojeva, postavljene su na vitke čelične konstrukcije koje imaju progibe. Sve to umnožava mogućnosti oštećenja. Kronologija popravaka može se pratiti u nizu grafita s potpisima majstora na tamburu kupole od 1908., 1911., 1913., 1923., 1937., 1938., 1963., 1974. do najnovijeg vremena. Potpisi isprava su kaligrafski, a poslije su ruke sve teže pisale imena, što odaje i pad kvalitete zanata u popravcima.

32 Kulturno-historijska izložba grada Zagreba prigodom Hiljadu-godišnjice Hrvatskog kraljevstva 925. - 1925., katalog izložbe, Zagreb, 1925., Raspored izložbenih prostorija, 38, shematski tlocrti obiju etaža.

33 MARINA BAGARIĆ, Arhitekt Ignjat Fischer, Zagreb, 2011., 255-256. 
34 Državni arhiv u Zagrebu, (bilj. 6), FRANJO BAHOVEC, O Umjetničkom paviljonu na Tomislavovom trgu, Gradski namještenik, 11, 1938., XV. Gradski građevni odsjek izradio je „Troškovnik za obnovu pročelja Umjetničkog paviljona na Tomislavovom trgu“ i u uvodnoj opaski daje Opće uvjete za radnje i nabave općine Grada Zagreba: „Obnoviće se cjelokupno pročelje zgrade uključivo vijenca, ukrasa, ornamenta i kiparije u besprikorno stanje u pogledu materijala i izvedbe, a po izgledu uglavnom kao što je bilo prije oštećenja, odnosno prema nacrtu. Ukrasi ornamenti i kiparije koje nisu izvedene u žbuci, već u drugom gradivu obnoviće se također, ukoliko nisu oštećeni, ili bi se mogli u dogledno vrijeme iskvariti... Opis radnja: ı. Cijelu žbuku uključivo svih vijenaca, istaka ornamenata i ukrasa ima se otući do zidja. Oštećene ukrase /ornamenata/ i kiparije od drugog materijala imaju se prema nalogu gradjevne uprave izvaditi odnosno ponovno ugraditi... Dijelove koji nisu u skladu s nacrtima imadu se srušiti i nadomjestiti novim prema nacrtu i uputi. Na naštrc ide gruba žbuka koja mora biti masna i ima se izvesti od oštrog posve čistog kopanog pijeska, cementa i vapna u omjeru 1:1:5. Fina žbuka ima se izvesti od prosijanog oštrozrnatog kopanog pijeska u običnom mortu sa pridodatkom cementa u 1/16 dijela i glatko zaribati. Gruboj i finoj žbuci ima se dodati Lotin P u smjesi 1:30 oko 2790 m2. 2. Bušenje zida podruma debljine $60 \mathrm{~cm}$ za prozore na sjevernoj strani sa izvedbom nadvoja, ugradbom doprozornika i popravcima žbuke, sve prema nacrtu kom 10..." Izvođači su izradili dokaznice mjera za svoje skupine radova, a obradio ih je arh. Franjo Bahovec. Predviđeni iznos od 200.000 din uvećan je 27. 3. 1939. odlukom Gradskog poglavarstva za 60.000 din. Komisija na čelu s gradskim vijećnicima, arh. Ignjatom Fischeom i ing. Ernestom Ehrlichom, predstavnicima XIV Građevnog odsjeka, arh. Franjom Bahovcem, arh. Ivanom Zemljakom, ing. Šištarom, predstavnikom Muzeja Grada i drugima, zapisnički su 30. siječnja 1939. izvještaj odbili, 6. srpnja dijelom prihvatili, a konačni obračun graditeljskih radova izvršen je 2. kolovoza 1939., a nadpohvalba radova održana je tek 26. rujna 1940., a i tada su uvjetovani popravci žbuke i boje. Istaknuta je uporaba termina obnova, širokog značenja - od popravaka do restauracije - uspostave prvotnog stanja, u hrvatskom jeziku prisutna od 19. stoljeća.

35 Državni arhiv u Zagrebu, (bilj. 6), kao dio „Pogodbe za obnovu pročelja Umjetničkog paviljona“ od 27. 9. 1938. s izvođačem su navedeni i nacrti. Na jedinom sačuvanom nacrtu, vrlo blijedoj crvenoj ozalidnoj kopiji, izvornog južnog pročelja u mjerilu 1:100, bez ikakvih natpisa ili oznaka, olovkom su dvjema kosim crtama prekriženi elementi koji se (privremeno?, kako stoji u bilj. 33) uklanjaju.

36 Državni arhiv u Zagrebu, (bilj. 6), tri dopisa o kandelabrima.

37 Državni arhiv u Zagrebu, (bilj. 6), tlocrt u mjerilu 1:100, na crvenoj ozalidnoj kopiji je natpis Umjetnički paviljon u Zagrebu, okrugli pečat paviljona i natpis „stanje 8. 1. 1954.“. Na istočnoj strani vestibula još su bile sanitarije građene 1898., poslije ravnateljeva soba, danas kustosova. 38 Arhiv Umjetničkog paviljona, hemeroteka. Šezdeset godina Umjetničkog paviljona, Borba, 1. 2. 1956., Strojarski projekt izradio je prof. dr. Milan Crlenjak s Tehnološkog fakulteta, a statički proračun Branko Vadlja, dipl. ing. građ. 39 Arhiva Konzervatorskog odjela u Zagrebu. Dopis Inžinjeringa zaprimljen 24. 4. 1968., koncept odgovora 27. 4. 1968., prof. Željko Filipec, i Rješenje Regionalnog zavoda za zaštitu spomenika kulture u Zagrebu, br. O2623/l-1968. od 30. 4. 1968. za obnovu krovne limarije i popravak kupole.

40 Katalog radova Restauratorskog zavoda Hrvatske 1966. - 1986., 139. Također i Arhiv Umjetničkog paviljona, HRZ, Aproksimativni troškovnik obnove, srpanj 1974. obradili dipl. ing. arh. Erika Piffl i dr. Ivo Maroević, s troškovnikom radova i projekata na 3.277.715 din.

41 Arhiv Umjetničkog paviljona. Ponudbeni troškovnik za izradu tehničke dokumentacije za obnovu Umjetničkog paviljona, 13. 9. 1977., sastavili su ak. Sl. Emil Pohl i arhitekti Josip Velnić i Gabrijela Šaban, na iznos od 930.000 din. Ponuda za izvedbu restauratorsko-konzervatorskih radova na zidnoj i stropnoj dekoraciji male dvorane, 9. 12. 1983., s fotografijama i projektom skele sastavili konzervatori: Mario Fučić, Dragan Dokić, Emil Pohl, na iznos od 4.265.768 din.

42 Arhiv Umjetničkog paviljona. Dopis RZH-u od 24. 11. 1983. Umjetnički paviljon je potvrdio prijam „tri aproksimativna troškovnika za popravak i obnovu štukature, slikarije, drvenine i dr." i zbog manjka sredstava pozvao na razgovor o parcijalnom opsegu početka radova u prosincu 1983. 43 Arhiv Umjetničkog paviljona. Inženjerski projektni zavod: projekti rasvjete 1974., gromobrana 1976. i Građevinski fakultet, Zavod za tehničku mehaniku i ispitivanje materijala i konstrukcija, provjera stabilnosti konstrukcije Umjetničkog paviljona, 25. veljače 1976.

44 Arhiv Umjetničkog paviljona. Arhitektonski projektni zavod: Plan, projekti obnove pročelja, uređenja razizemlja i kotlovnice i interijera, rasvjete i dr. s fotografijama, pet registratora.

45 Arhiv Umjetničkog paviljona. Zavod za katastar i geodetske poslove grada Zagreba: fotogrametrijska snimka postojećeg stanja svih pročelja, travanj 1984.

46 Arhiv Umjetničkog paviljona. APZ Plan: nadzori, dokumentacija Zagrebgradnje, osnovni ugovor i tri dopunska, naknadni radovi, razizemlje, obračun razlike, građevinski dnevnici i građ. knjige. Nakon okončane situacije od 29. 9. 1987. fakturirano je 57.765.539 din, a nadzorom tada odobreno 47.244.712 din.

47 Arhiv Umjetničkog paviljona. Plan je 30. 12. 1985. zatražio od RZH-a „Ponudu za izvedbu radova restauracije“ unutrašnjosti, a 20. 1. 1986. RZH je odgovorio da prema priloženom troškovniku ne može dati ponudu i u dopisu 
od 23. 6. 1986. detaljno iznio kronologiju pokušaja stručnog pristupa radovima.

48 Arhiv Umjetničkog paviljona. „Prijedlog za obnovu dekoracije u Umjetničkom paviljonu, pripremio akad. slik. prof. Vladimir Pavlek 15. prosinca 1986“. Dozvola Regionalnog zavoda za zaštitu spomenika kulture u Zagrebu izdana je 6. 1. 1987., a ponuda za „pojačani konzervatorski nadzor" nad radovima u interijeru 2. 3. 1987. Vladimir Pavlek (1838. - 1913.), nakon Škole primijenjene umjetnosti 1960., diplomirao je na slikarskom odjelu Umjetničke akademije u Zagrebu 1964. u klasi prof. Otona Postružnika. Radio je kao profesor na Građevinskom školskom centru u Zagrebu. Bavio se restauratorskim radom uglavnom na sakralnim objektima, u Zagrebu (na katedrali, Nadbiskupskom dvoru, Banskim dvorima, Preporodnoj dvorani, arkadama na Mirogoju, crkvama u Palmotićevoj i Granešini), Đakovu, Mariji Bistrici, Samoboru, Gornjoj Stubici, Lužnici i dr. 49 Arhiv Umjetničkog paviljona, APZ Plan.

50 GzzSKıP, Odjel za dokumentaciju, fototeka, zatečeno stanje svih dijelova pročelja i krovova detaljno je dokumentirano.

51 Arhiv Umjetničkog paviljona. Interijer vestibula 1997. 52 Arhiv Umjetničkog paviljona. Klima Zagreb, GzZSKIP, smjernice 15. 7. 2001. i 29. 7. 2002. za postavu klimatizacijskih komora u šahtove.

53 Arhiv Umjetničkog paviljona. D.i.a.s, mišljenje czzsKIPa od 14. 12. 2004. na izmijenjenu varijantu projekta iz rujna 2004. lako je izrađen i glavni projekt, do izvedbe nije došlo zbog nedostatka sredstava.

54 Arhiv Umjetničkog paviljona. Projekti Baština, Škoro, Projekting - 1970. Smjernice GZZSKIP-a 24. 4. 2006., Rješenje Zavoda na glavni izmijenjeni projekt 12. 7. 2006. Izvedbu je organizirao i vodio Gradski ured za prostorno uređenje, zaštitu okoliša, izgradnju Grada, graditeljstvo, komunalne poslove i promet, Sektor za građenje objekata društvenih djelatnosti i stanogradnju.

55 Dokumentacija GzzskıP-a (bilj. 50). Konzervatorske smjernice izrađene su nakon pregleda dokumentacije $u$ Povijesnom arhivu u Zagrebu, Nadbiskupskom arhivu, fototeci Muzeja grada Zagreba, Konzervatorskom odjelu u Zagrebu, czzskıP-u i drugdje, kako je navedeno u prethodnim bilješkama. Analizirana je detaljna izvedbena dokumentacija i niz fotografija izvornog i novosnimljenog zatečenog stanja. Konzultirana je i temeljna stručna literatura MICHAEL PETZET, Principles of preservation, ICOMOS, 2004., 9-21, IVO MAROEVIĆ, Sadašnjost baštine, 1986., 7889. Gradu 1938. nije bila namjera stvoriti novu vrijednost arhitektonskog oblikovanja jer je namjeravao obnoviti i ukrase (bilj. 34), ali su izvedeni samo graditeljsko-obrtnički radovi. Dodana su dva betonska elementa, vrh dimnjaka u obliku vaze i akroterij, koji se jedini planiraju skinuti zbog lošeg stanja.

56 Dokumentacija czzskı P-a, (bilj. 50). Projekt je predan 2. 2. 2007. Budući da je u troškovniku nedostajao niz radova, projektantica, arhitektica Svjetlana Horvat Jelić pozvana je na konzultacije i zaključkom GzzsKıP-a, 14. 2. 2007. zatražene su dopune, koje je izradio ing. Plenković i ponovio zahtjev 26. 3. 2007. pa je 27. 4. 2007. izdano rješenje - Klasa: UP/I-612-08/07-06/193, s nizom uvjeta za izvedbu.

57 Dokumentacija czzskıP-a, (bilj. 50). Službena bilješka u predmetu konz. nadzora - Klasa: 612-08/07-10/395. Najprije je skelu, koju je izveo postavljač reklama, trebalo doraditi i približiti pročeljima da se može raditi. Određena su mjesta izrade četrdesetak restauratorskih sondi na kupoli i pročeljima, na svim materijalima, žbuci, limu, drvu i metalu i dokumentiranje izvještajem.

58 Dokumentacija czzskı P-a, (bilj. 50). Uz troškovnik su izrađeni i nacrti svih pročelja i označene pozicije stavaka, u dva kompleta (jedan za specijalističke zidarske radove lučnih profilacija i drugi za restauratorske radove).

59 Gradski ured za prostorno uređenje, zaštitu okoliša, izgradnju Grada, graditeljstvo, komunalne poslove i promet, Sektor za građenje objekata društvenih djelatnosti i stanogradnju, arhiva Klasa 361-02/06-014/65, 11. 11. 2007. MČP i dr., dokumentacija: ugovori i zapisnici koordinacija gradilišta, izvješća nadzornog organa 8. 1. 2010. i 14. 5 . 2013., građevinski dnevnici i knjige izvođača s izvedbenim detaljima, nacrtima šablona u mj. 1:1, zapisnici o primopredaji radova, obračuni i dr.

60 Prethodno su navedene količine novih žbuka u radovima 1938. i 1986. Međutim, iskazane količine obračunate su, zbog razvedenosti pročelja, s faktorima. Izvorna je žbuka bila sačuvana uglavnom oko arhitektonske i skulptoralne plastike, u timpanima, nišama, na tamburu i drugdje. Ti su slojevi zadržani i žbuka je sanirana.

61 Gradski ured (bilj. 59), atesti materijala uz zapisnike o primopredaji. Silikonske boje su odabrane zbog postojanosti i veće trajnosti od mineralnih na lokaciji uz tri intenzivne prometnice i atmosferska onečišćenja. Primijenjena je tehnologija StoLotusan Color, s efektom lotosova lista, samočišćenja od oborina, što se na zgradi u blizini u petnaest godina pokazalo dobrim.

62 Restauratorska obrada arhitektonske i skulptoralne plastike rađena je materijalima prema uputama tehnologa i voditelja tvrtke Röfix, Ivice Prskala, dipl. ing. građ., s mineralnim žbukama za dublje i finije slojeve (Renostar i Renoplus).

63 Gradski ured (bilj. 59), dokumentacija i izvješće nadzornog organa od 14. 5. 2013.

64 Vidi: NIKOLINA HRUST, Obnova Umjetničkog paviljona u Zagrebu 2006. - 2011., Zbornik radova 2. kongresa hrvatskih muzealaca, Zagreb, 2013., 261-272; IRENA KRAŠEVAC, Paviljonovo novo ruho, Kvartal 3-4, 2013., 44-46; MLADEN PERUŠıĆ, Umjetnički paviljon - O gradnji i građevini kroz stotinu deset godina, Zagreb, moj grad, br. 2/2009. i br. 35/2011., Umjetnički paviljon - europska poveznica, 2013. 


\section{Abstract}

\section{Mladen Perušić}

\section{BUILDING AND RENOVATIONS OF THE ART PAVILION IN ZAGREB}

The Art Pavilion was entered in the Register of Cultural Goods of the Ministry of Culture of Republic of Croatia due to it being a preserved free-standing building on a square within the Green Horseshoe.

It was built in 1896 for the 1898 Millennial Exhibition in Budapest as a building with a central layout, a dome and side wings, that is lit from above according to the contemporary European standards for this type of building. The project selected at the competition was that of Hungarian architects Floris Korb and Kálmán Giergl. The Tripartite Kingdom decreed that the steel structure manufactured by the Danubius company be transferred to Zagreb to form the core of the Art Pavilion. The location for the City House of the Arts was chosen while anticipating the city's expansion and it was decided that such a prominent location requires imposing architecture, so the project of reconstruction was entrusted to Viennese architects Fellner and Helmer and the construction work to the Zagreb company Hönigsberg Q D Deutsch. Due to the difference in ground levels, the building was constructed in two storeys, with the upper story housing the exhibition space, while the lower story was to be used as a restaurant and cafe. The Pavilion was opened on December $15^{\text {th }} 1898$ with the exhibition of the Croatian Salon of the Arts Society. In the course of one hundred years of building alterations, the Pavilion has lost some of its original appearance, mostly notably in 1938 when a radical purification was carried out due to the building's poor condition and the contemporary view of historicist architecture, seeing portions of the architectural sculpture removed, such as turrets next to the dome, urns at the roofs' edges, acroterions, cornices with the coats of arms of the Tripartite Kingdom, masquerons in keystones of the niches, hermae and the bust of Athena above the entrance, etc. The next major renovation in 1986 saw only construction craft work carried out.

The recent comprehensive renovation of the Art Pavilion, a symbol of Zagreb, got under way in 2006 . The poor condition of the building, the roofs, the dome and the façades with only a portion of their decorations left, was a pale image of the original imposing architecture. After compiling archival records, projects, and bibliography, as well as historical and the most recent photo documentation, the conservators drew up guidelines and a cost estimate for the renovation to be done by way of restoring the building to its original state, as it was established that there were enough elements to do so. The City of Zagreb, as the Art Pavilion's owner and as investor, enlisted the renovation in the programme of monument annuity. The sector for communal buildings of the City Office for Construction organized the renovation in several phases: in 2006 the lighting of the exhibition space and the glass roofs over the halls were installed, from 2007 to 2011 the dome and all the façades were renovated, and before 2013 the construction and installation improvement inside the building was completed and architectural sculpture set up. The most complex procedure was the removal of the metal sheets on shorter sides of the octagonal dome transported from Budapest and the installation of glass as designed in the project of Fellner and Helmer. A special attention was put to the conservation work carried out in four sets: the elements restored in situ, those which were dismantled and renovated in the workshop - mostly from zinc-plated metal sheets, the fabrication of new ones after the existing samples in portions where they were missing, and the re-creation of those removed in 1938 after old plans and photographs. The conservation work was concluded with the installation of the reconstructed entrance portal with hermae and the bust of Athena, protectress of arts and crafts. The comprehensive renovation of the Art Pavilion exterior was completed in 2013 according to the concept of restitution of the original 1898 situation. This was opted for as the imposing building occupies a prominent location within the Zagreb Green Horseshoe and the city traffic circulation, and was possible because of the sufficient data available.

Given the recent conservation, this article aims to outline the historical phases of the Pavilion and their valorization that served as basis for the presentation proposed. It reveals the so far unknown information and details, providing an architectural analysis of the building, its geometry and structure, based on archival and conservation research and the renovation performed, whereby a model of presentation chosen was that of the last live layer which is also the first, and where the interventions applied entailed conservation of the original object in situ.

KEYwORDS: Art Pavilion in Zagreb, construction, building alterations, recent renovation 